\title{
Chronology and sources of trace elements accumulation in the Rhône pro-delta sediments (Northwestern Mediterranean) during the last 400years
}

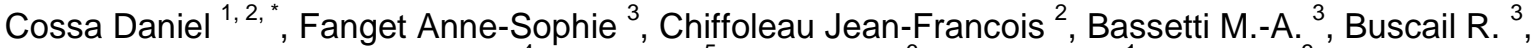 \\ Dennielou Bernard ${ }^{4}$, Briggs K. ${ }^{5}$, Arnaud M. ${ }^{6}$, Guédron S. ${ }^{1}$, Berné S. ${ }^{3}$
}

${ }^{1}$ ISTerre, Université Grenoble Alpes, BP 53, F-38041 Grenoble, France

${ }^{2}$ Ifremer, LBCM, BP 21105, F-44311 Nantes, France

${ }^{3}$ Université de Perpignan, Cefrem, 52, Ave. P. Alduy, F-66860 Perpignan Cedex, France

${ }^{4}$ Ifremer, Geosciences marines, BP 70, F-29280 Plouzané, France

${ }^{5}$ Department of Physics, University of Ottawa, Ottawa (Ontario) K1N 6N5, Canada

${ }^{6}$ IRSN, BP 330, F-83507 La Seyne-sur-Mer, France

*Corresponding author : Daniel Cossa, email address : dcossa@ifremer.fr

\begin{abstract}
:
The Rhône pro-delta sediments receive the particulate inputs from the Rhône River, the largest freshwater discharge of the Western Mediterranean Sea. Trace element (TEs: Ag, Cd, Co, Cr, Cu, Ni, $\mathrm{Pb}$, and $\mathrm{Zn}$ ) concentrations and stable $\mathrm{Pb}$ isotope ratios were determined along a 7.7-meter-long sediment core collected from the Rhône prodeltaic lobe, archiving the deposits of the last 400 years. Trace element mean concentrations during the pre-industrialized era (before $1850 \mathrm{AD}$ ) were no different from the average composition of Earth's upper crust, except for Cr. Principal component analysis, performed on TEs and tracers, suggests three origins for TEs that we identified as (i) marine biogenic material $(\mathrm{Ag}, \mathrm{Cd})$, (ii) ultramafic rocks ( $\mathrm{Li}, \mathrm{Cr}, \mathrm{Ni}$ ), and (iii) other clay minerals (Co, $\mathrm{Cu}, \mathrm{Pb}$ and $\mathrm{Zn}$ ). During the pre-industrial period, several changes in the TE/Al ratios coincided with flood events or/and modifications in the channelization of the Rhône River mouth. Some frequencies in the TEs temporal variations allow us to hypothesize some influence of climate variation. Sediments deposited after 1850 AD exhibited concentrations of certain TEs exceeding 1.3 to 3.5 times the concentrations of the preindustrial era $(\mathrm{Ag}>\mathrm{Cd}-\mathrm{Pb}>\mathrm{Cu}-\mathrm{Zn})$. Principal component analysis, performed on post-1850 AD data, allows to distinguish pristine and "anthropogenically impacted" TEs. Pristine TEs, such as Co, Cr, and $\mathrm{Ni}$, are linked with clay markers ( $\mathrm{Al}, \mathrm{Li}$ and $\mathrm{Fe}$ ), $\mathrm{Co}$ and $\mathrm{Ni}$ are associated with $\mathrm{Mn}$-enrichment, whereas $\mathrm{Cr}$ is correlated with Fe. "Anthropogenically impacted" elements consist of $\mathrm{Ag}, \mathrm{Cd}, \mathrm{Cu}, \mathrm{Pb}$, and $\mathrm{Zn}$. Vertical profiles show that TE contamination has increased dramatically after the IInd World War and reached a maximum between 1970 and 1980, consistently with anthropogenic atmospheric emissions changes. Sediment deposited on the Rhône prodelta at the beginning of XVIlth Century have $206 / 207 \mathrm{~Pb}$ ratios close to values of natural $\mathrm{Pb}(1.200)$, whereas sediments deposited after $1850 \mathrm{AD}$ are clearly contaminated by European gasoline and industrial $\mathrm{Pb}$ pools $(<1.180)$. In addition, peak-events can be related to flooding periods, natural and man-induced channelization of the Rhône River mouth, or diagenetic processes.
\end{abstract}




\section{Highlights}

- Trace elements are accumulated in the Rhône prodelta sediments. Preindustrial sediments recorded floods and channelization of the Rhône River. Contamination reached a maximum between 1970 and 1980 AD. 


\section{Introduction}

As stated by the international Geotraces program (www.geotraces.org), many trace elements (TEs) are critical for marine life, and therefore influence the functioning of ocean ecosystems and the global carbon cycle. Indeed, they are micronutrients essential to life (e.g. Fe, $\mathrm{Zn}, \mathrm{Cu}$ ), tracers of modern processes in the ocean (e.g. Al, Mn), and are significantly perturbed by human activities (e.g. $\mathrm{Pb}$ ). In the Western Mediterranean, the biogeochemical cycling of TEs is largely governed by atmospheric inputs (Migon et al., 2002). However, the influence of rivers on TE distributions is discernible in the sediments of the adjacent continental shelf (Ferrand et al., 1999; Roussiez et al., 2005 and 2006; Radakovich et al., 2008). According to the Mermex Group review (The Mermex Group, 2011), present and past inputs of riverine particulate TEs to the Mediterranean, especially anthropogenic TEs, need to be more precisely estimated.

Estuary and delta sediments are suitable environments to reconstruct historical accumulation of elements and anthropogenic chemicals from continental and marine sources during last centuries or even millennia (e.g., Valette-Silver, 1993; Santschi et al., 2001; Callender, 2003). In particular, this is the case for the Rhône prodeltaic prism, which receives particulate inputs from the Rhône River (RR), and has archived its inputs for centuries (Fanget et al., 2013). Studying this area provides a unique opportunity to document the chronology and the sources of the TE inputs from the largest riverine sediment source to the Mediterranean Sea.

Here, we document the temporal accumulation of TEs $(\mathrm{Ag}, \mathrm{Cd}, \mathrm{Co}, \mathrm{Cr}, \mathrm{Cu}, \mathrm{Ni}, \mathrm{Pb}$ and its stable isotopes, and $\mathrm{Zn}$ ) in sediment recovered in the Roustan lobe within the Rhône prodelta area, located on the continental shelf of the North side of the Western Mediterranean (Fig. 1). Based on a multiproxy study, including major elements and radiometric analyses, we have been able to identify the major changes in TE accumulation in the Rhône prodelta sediments during the last four centuries. These changes are discussed in terms of hydrological regime, channelization of the RR mouth, climate change, and TE contamination history.

\section{Study area}

The RR and its tributaries drain various catchments including sedimentary rocks, granitic, and metamorphic rocks from the Alps, Massif Central, and Vosges. In addition, RR carries alluvium 
from one of the most industrialized and urbanized European catchments (The Mermex Group, 2011). The RR sediment load has varied significantly during the past few centuries Since the XIX ${ }^{\text {th }}$ Century, it has decreased by a factor close to ten, mainly because of stabilization of mountain slopes due to decline of rural agriculture and reforestation, and to a lesser extent because of damming and dredging activities (Pont et al., 2002; Maillet et al., 2006a; Provansal et al., 2014). However, since the completion of damming of the Nile in 1970, the RR is the largest source of continental sediment for the Mediterranean Sea. The annual solid discharge during the last decades was highly variable, from 2 to $20 \cdot 10^{12} \mathrm{~g} \mathrm{yr}^{-1}$ (Mtons $\mathrm{yr}^{-1}$ ) (Pont et al., 2002; Antonelli et al., 2004; Sabatier et al., 2006; Launay, 2014), with an average flux of $3.2 \cdot 10^{12} \mathrm{~g} \mathrm{yr}^{-1}$ for the last 30 years (Gairoard et al., 2012). Sediments delivered by the RR are entrapped in the prodelta, with sediment accumulation rates varying from $50 \mathrm{~cm} \mathrm{yr}^{-1}$ at the mouth to $0.2 \mathrm{~cm} \mathrm{yr}^{-1}$ at $20 \mathrm{~km}$ seaward (Calmet and Fernandez, 1990; Charmasson et al., 1998; Radakovitch et al., 1999; Miralles et al., 2005). Eighty percent of particulate load of the RR is delivered during flood events (Pont et al., 2002), creating stratified structure in the prodelta sediments (Fanget et al., 2013) which is superimposed over longer-term trends of accumulating sediments.

According to the review of the centennial hydrological changes by Fanget et al. (2013), the chronology of floods is quite well documented from 1500 to 1995 AD. First, a mean of 4 to 5 major floods occurred per decade between 1500 and 1650 AD. Second, from the XVII ${ }^{\text {th }}$ Century climatic minimum to the $\mathrm{XIX}^{\text {th }}$ Century, corresponding to the Little Ice Age (LIA), the frequency of floods increased, with 10-20 major floods in 1701-1710, 1751-1760, 1771-1780 and 1811-1820 AD. The flood frequency has decreased since the end of LIA (Pichard, 1995), from 8-9 per decade at the ends of the XIX ${ }^{\text {th }}$ Century, to 2-3 per decade at the end of the $\mathrm{XX}^{\text {th }}$ Century. Since that time, the 2003 AD flood and its associated seabed morphological changes have been extensively studied (Eyrolle et al., 2006; Maillet et al., 2006b; Miralles et al., 2006b; Antonelli et al., 2008). The geomorphology of the RR mouth has been modified several times as a result of natural stresses and/or human-induced channelizations. After the major floods between 1709 and $1711 \mathrm{AD}$, the Bras de Fer lobe formed during the LIA (Arnaud-Fassetta, 1998) was displaced eastward (Fig. 1). Between 1711 and 1852 AD, the RR displayed three mouths (Piémanson, Roustan and Pégoulier mouths, Fig. 1). In 1855 AD, in order to improve fluvial navigation, the Piémanson and Roustan mouths were closed, and in 1892 AD the Roustan mouth was re-opened for navigation and the Pégoulier channel was progressively filled. Since 1892 AD, the Roustan mouth is the only exit of 
the Grand Rhône (Fig. 1), the foremost distributary channel of the RR discharging into the Mediterranean.

\section{Material and Methods}

\subsection{Core collection}

This study is based on a multi-proxy analysis of a $7.71 \mathrm{~m}$-long piston core (KS57, Fig. 1) collected on the Roustan prodeltaic lobe $\left(43^{\circ} 17.10^{\prime} \mathrm{N} ; 4^{\circ} 50.97^{\prime} \mathrm{E}\right)$ at $79 \mathrm{~m}$ water depth during the RHOSOS cruise in September 2008 aboard R/V Le Suroît. The core was sliced every $2 \mathrm{~cm}$ from $2 \mathrm{~cm}$ below the sediment-water interface (SWI) to $100 \mathrm{~cm}$, then every $4 \mathrm{~cm}$ down to the bottom of the core, which was $767 \mathrm{~cm}$ below the SWI. Subsamples were frozen $\left(-18^{\circ} \mathrm{C}\right)$, freeze-dried and stored under cold $\left(4^{\circ} \mathrm{C}\right)$ and dark conditions until analysis.

\subsection{Chemical analyses}

Iron $(\mathrm{Fe})$ and $\mathrm{Al}$ concentrations were determined by atomic absorption spectrophotometry (AAS, SpectrAA $600^{\circledR}$, Varian). Aluminium (Al), Co, Cr, Cu, Li, Ni, Zn, and $\mathrm{Pb}$ (including its stable isotopes) analyses were performed after total dissolution of the sediment with a mixture of $\mathrm{HCl}, \mathrm{HNO}_{3}$, and $\mathrm{HF}$ in hermetically sealed Teflon bombs according to the protocol described by Loring and Rantala (1990) and modified by Chiffoleau et al. (2004). For Ag and Cd, in order to avoid interferences with ICP-MS, the sediment was digested using only $\mathrm{HCl}$ and $\mathrm{HNO}_{3}$. All reagents used were SupraPur ${ }^{\circledR}$ (Merck). Concentrations were determined using inductively coupled plasma mass spectrometry (ICP-MS, Element X Series ${ }^{\circledR}$, Thermo Electron Corporation). The results were validated using certified reference materials (CRM), MESS-3 and BCSS-1 from the National Research Council of Canada. A blank sample and CRM were included with each batch of 15 samples in the total digestion procedure and then analyzed with ICP-MS and AAS. The blank values were always below the detection limits. Values obtained for major element analysis were always within the range of certified values (Table S1).

Organic matter $(\mathrm{OM})$ is estimated using organic carbon $\left(\mathrm{C}_{\mathrm{org}}\right)$ content. Total carbon $\left(\mathrm{C}_{\mathrm{t}}\right)$ and organic carbon $\left(\mathrm{C}_{\mathrm{org}}\right)$ were determined using freeze-dried and homogenized subsamples of sediments with an elemental analyzer (Model CN 2000 ${ }^{\circledR}$, LECO) after acidification with 2M HCl (overnight, at $50^{\circ} \mathrm{C}$ ) for $\mathrm{C}_{\text {org }}$ in order to remove carbonates (Cauwet et al., 1990). The precision for 
$\mathrm{C}_{\text {org }}$ and $\mathrm{C}_{\mathrm{t}}$ analyses was $\pm 2 \%$. Concentrations are expressed as the weight percent of dry sediment (\% dry weight). Calcium carbonate content was calculated from mineral carbon $\left(\mathrm{C}_{\mathrm{t}}-\mathrm{C}_{\mathrm{org}}\right)$ using the molecular mass ratio $\mathrm{CaCO}_{3}: \mathrm{C}=100: 12$.

\subsection{Numerical treatment, statistical analyses, and normalization}

We applied Principle Component Analysis (PCA), a multivariate technique in which the numbers of variables is reduced to a smaller number of factors that describe the principal variability or joint behavior of the data set. Geometrically, this new set of variables represents a principal axis rotation of the original coordinate axes of the variables around their mean (Jackson, 1991; Huang et al., 2010). The statistical computations were performed with XLSTAT® software from Addinsoft.

Spectral analysis is performed using the Lomb-Scargle Periodogram, a generalization of the Fast Fourier Transform to data sets with non-uniform sampling period (http://www.peranso.com/). The false alarm probability (p-value) for every point in the periodogram is estimated in order to determine the periods of significant cycles in the data. Peak frequencies are found using a first-order difference scheme that identifies local maxima in the periodograms, and errors in the location of peaks are estimated as the distance halfway between a local maximum and the nearest local minimum in the periodogram, or one-quarter of the natural line-width of frequency peaks, whichever is larger. In an ideal case, these two estimates are approximately equal.

In order to test if the observed variations in the profiles were the result of mineral changes within the cores, the trace element concentrations were geochemically normalized by the use of tracer elements (Kersten and Smedes, 2002). Aluminum was chosen as the granulometric normalizing element to take into account the clay fraction with its high specific surface, which favors metal binding for $\mathrm{Co}, \mathrm{Cr}, \mathrm{Cu}, \mathrm{Ni}, \mathrm{Pb}, \mathrm{V}$ and $\mathrm{Zn}$ (e.g., Windom et al., 1989).

\section{Results and discussion}

\subsection{Characterization of sediment core}

The dating of core has been established based on ${ }^{210} \mathrm{~Pb},{ }^{137} \mathrm{Cs}$ vertical profiles and microfossil assemblages (ostracods, benthic foraminifera, and coccoliths) in combination with sedimentological 
proxies (Fanget et al., 2013). Herein, we present our geochemical results based on this wellconstrained chronology. This $7.67 \mathrm{~m}$ core covers a period of just over 400 years. The first $3.75 \mathrm{~m}$ below the SWI has accumulated since the middle of the XIX ${ }^{\text {th }}$ Century, corresponding roughly to the beginning of the industrial era in Europe. Figure S1 gives the relationship between depth and date of the deposits in core.

During the modern history of the subaqueous Rhône delta, both fluvial and marine inputs have occurred. Fanget et al. (2013) proposed that the structure of core KS57 can be summarized by four different periods (Intervals I-IV), spanning a time range between 1600 AD and the sampling date (i.e., 2008 AD), corresponding to different positions of distributary-channels induced by climate events and/or by human activities. Low RR influence is observed between 1600-1711 AD (Interval I) and 1855-1892 AD (Interval III). These periods correspond to the time when the RR was flowing into the Mediterranean through the Bras de Fer channel (i.e., at the westernmost side of delta system) and the Pégoulier channel (i.e., at the easternmost side of delta system) respectively (Fig. 1). Conversely, significant RR influence can be detected between 1711-1855 AD (Interval II) and 1892-Present-day (Interval IV). During Interval II, the RR had three mouths (Piémanson, Roustan, and Pégoulier mouth) and the sediments accumulated on the Grand Rhône lobe; during Interval IV, the Piémanson et Pégoulier mouths were artificially closed and the sediments accumulated on the Roustan lobe (Fig. 1). The strongest riverine influence is recorded when the RR mouth was within the modern Roustan channel, i.e., just in front of the KS57 core location.

The $\mathrm{Al}, \mathrm{Fe}$ and $\mathrm{Li}$ profiles confirm and allow us to refine the previously described chronological patterns (Fig. 2abc). Low concentration values of these clay mineral proxies occurred around 1700, 1855, 1895, and $1995 \mathrm{AD}$, dates which match the boundaries between Intervals I, II, III, and IV, and close to the SWI respectively. These low values are characteristic of low clay contribution, which suggests the presence of sandy layers, such as the one already pointed out at $\sim 270 \mathrm{~cm}$ below the SWI ( 1900 AD) by Fanget et al. (2013). These structures indicate that sedimentation changes have occurred during channel modifications and flooding events. Firstly, several changes occurred between 1700 and $1710 \mathrm{AD}$, i.e. at the boundary between intervals I and II (Fig. 2). In 1702, huge floods occurred in Haute Provence, following which the Bras de Fer Branch (Fig. 1) was progressively filled with RR alluviums, and in 1706, the Launes channel (east of Bras de Fer) was created (Pichard, 1995; Provansal et al., 2003). Secondly, after 1890, the Roustan mouth was opened for navigation and the Pégoulier channel was progressively filled in. 
Thirdly, and more recently, huge floods of the RR were recorded during the period from October 1993 to February 1994 (e.g., Arnaud-Fassetta, 2003). During these three periods, the concentrations of $\mathrm{Al}$ and Fe were sharply depleted (Fig. 2ab). In addition, within Interval III, we observed Lienriched sediment (Fig. 2c). In this case, Li enrichment alone (i.e., without $\mathrm{Al}$ or Fe) would not trace clay mineral as usually expected (Loring, 1991), but may indicate an increasing influence of marine material. This hypothesis is supported by the presence of marine ostracod assemblages within Interval III (see figure 7 in Fanget et al., 2013). This connection between the abundance of marine ostracods and the Li-specific enrichment is also observed in the first part of Interval I, corresponding to the period 1600 and $1670 \mathrm{AD}$; indeed, abrupt changes can be seen in the $\mathrm{Li} / \mathrm{Al}$ ratio profile (Fig. S2).

Some insights into the early diagenetic processes occurring in the core, which may contribute to the conditions of TE accumulation on the Roustan lobe, can be deduced from the OM vertical distribution in the core. Indeed, $\mathrm{C}_{\text {org }}$ concentrations decreased with depth in the first $\sim 270 \mathrm{~cm}$ below SWI, i.e., within Interval IV (Fig. 3). Below, $\mathrm{C}_{\text {org }}$ remained quite unchanged down to the bottom of the core. The redox potential discontinuity was at $2.7 \mathrm{~cm}$ below the SWI for a sediment core taken in May 2008 at the same location $(79 \mathrm{~m})$ on the Roustan lobe with a multitube-corer, which preserved the SWI. This result is consistent with the oxygen penetration depth (OPD) of $5 \mathrm{~mm}$ measured in situ by microelectrodes in this sediment (Cathalot et al., 2010). This result is consistent with the extensive microelectrode measurements in Roustan lobe, which indicate that oxygen rarely penetrates more than $5 \mathrm{~cm}$ in the sediment (Cathalot et al., 2010). Thus, we can conclude that an important fraction of the OM mineralized under anaerobic conditions, as suggested by GarciaGarcia et al. (2006). In the Interval IV, i.e., between 0 and $270 \mathrm{~cm}$, the carbonate concentration (Fig. S3) is consistent with the results of Rassmann et al. (2016), with a rapid decrease just below the SWI (corresponding to aerobic oxidation) followed by an steady increase (corresponding to anaerobic degradation). Below $270 \mathrm{~cm}$, carbonate content steadily decreased from $45 \%$ to $35 \%$ with depth (Fig. S3). This feature of carbonate (in situ) dissolution suggests the persistence of OM degradation (e.g., Emerson and Bender, 1981). Both autochthonous biogenic and continental detrital carbonates (from calcareous outcrops in the RR basin) can contribute to the carbonate content of the sediments of the prodelta region, and it is known that the carbonate dissolution rate depends upon its mineral origin: aragonite, which constitutes most of carbonate deposited in shallow environments, is more rapidly dissolved than calcite (Mucci, 1983). It is interesting to note that 
according to Fanget et al. (2013), core KS57 mainly consists, from its bottom to $270 \mathrm{~cm}$ (Intervals I and III), of homogeneous silty clay with abundant iron sulfide, and between $\sim 270 \mathrm{~cm}$ and the SWI (Interval IV) of laminated grayish and brownish silty clay. In brief, our data suggest that the degradation of OM is active in Interval IV, but weak below. As expected, the OM degradation rate is diminished in sulfidic sediments. However, the diagenetic context is more complex, since the $\mathrm{Mn} / \mathrm{Li}$ profile show peaks at 47, 270 and $610 \mathrm{~cm}$ (Fig. S4). These peaks suggest the presence of relicts of oxic SWI lying at these depths, which would correspond to drastic changes in the sedimentary conditions. Indeed, a Mn-enriched layer points to $\mathrm{Mn}^{\mathrm{IV}}$ precipitation as $\mathrm{Mn}$ oxihydroxides, when dissolved $\mathrm{Mn}^{\mathrm{II}}$ diffusing from below encounters molecular $\mathrm{O}_{2}$ diffusing from the underlying water column (e.g., Burdige and Gieskes, 1983). These oxihydroxides are known for their efficient adsorptive properties for TEs (e.g., Gadde and Laitinen, 1974). The main peak, at $\sim 270 \mathrm{~cm}$, corresponds to the reopening of the Roustan channel at the end of the XIX ${ }^{\text {th }}$ Century; the peaks at 47 and at $610 \mathrm{~cm}$ correspond to the huge flooding periods, 1993-1994, and at the very end of the XVII ${ }^{\text {th }}$ Century respectively (Fig. S4). The observation of multiple Mn peaks in sediment is not uncommon, and has been interpreted as the result of non-steady-state diagenesis due to changes in the carbon cycle (e.g., Deflandre et al., 2002; Kuzyk et al., 2011) or in turbidite sequences (e.g., Colley et al., 1984).

\subsection{Trace elements behavior before industrialized era}

Table 1 summarizes statistics on TE concentrations measured in sliced layers of core. We have arbitrary defined, as usually admitted, the European industrial era as the Second Industrial Revolution, i.e., a period starting 1850 AD. We checked this choice using ${ }^{206 / 207} \mathrm{~Pb}$ and ${ }^{206 / 204} \mathrm{~Pb}$ isotopic ratios to qualify metal anthropization. ${ }^{206 / 204} \mathrm{~Pb}$ were higher than 18.67 before $1850 \mathrm{AD}$, ranging between 18.85 and 18.67, whereas after this date, values were lower than 18.67, down to 18.33 (Fig. 4). On the other hand, in spite of a slight steady decrease of the ${ }^{206 / 207} \mathrm{~Pb}$ isotopic ratios from $\sim 1.20$ to $\sim 1.93$ corresponding to the period between 1600 and 1850 AD (especially during the $\mathrm{XVII}^{\text {th }}$ Century), the beginning of the huge decrease in the ratios (down to 1.175) also occurred around $1850 \mathrm{AD}$. Thus, TE mean concentrations during the pre-industrialized era were in most cases low, but for $\mathrm{Ag}\left(0.10 \pm 0.02 \mu \mathrm{g} \mathrm{g}^{-1}\right), \mathrm{Cd}\left(0.17 \pm 0.02 \mu \mathrm{g} \mathrm{g}^{-1}\right)$ and especially $\mathrm{Cr}\left(70 \pm 4 \mu \mathrm{g} \mathrm{g}^{-1}\right)$, higher than the average composition of Earth's upper crust (EUC, Table 1). The mean concentration of these TEs are in the range of pre-industrial concentrations found in the deepest part of the 
sediment cores collected in the Cap de Creus canyon along the Northwestern Mediterranean margin (Cossa et al., 2014). Relatively high $\mathrm{Cr}$ concentrations $\left(\sim 70 \mu \mathrm{g} \mathrm{g}^{-1}\right)$ were also measured during Rhône river flooding events (Radakovitch et al., 2008), and could be the result of naturally enriched minerals. Indeed, relatively high $\mathrm{Cr}$ contents are found in pristine suspended load of the Po River originating from the Western Alps as a result of the erosion of ultramafic rocks (ophiolite) (Amorosi, 2012). Ag and Cd pre-industrial concentrations are not yet documented for the RR basin, and more research is needed in that respect. TE concentrations were quite correlated with each other in the pre-industrial period, suggesting, at a first approximation, common origins $(\mathrm{p}<0.01$, Table 2$)$. $\mathrm{Ag}$ is an exception since it is only significantly correlated $(\mathrm{p}<0.01)$ with $\mathrm{Cd}$. However, based on the results of a PCA, this allows sorting out three groups of TEs based on their common variations (Table 3a, Fig. S5a). One group combines $\mathrm{Li}, \mathrm{Cr}$ and $\mathrm{Ni}$, another combines $\mathrm{Co}, \mathrm{Cu}, \mathrm{Pb}$ and $\mathrm{Zn}$, and the third combines $\mathrm{Ag}, \mathrm{Cd}$ and carbonates. $\mathrm{Al}$ and $\mathrm{Mn}$ are both associated with the first and the second group, and the second and the third, respectively (Fig. S5). It can be reasonably speculated that the first group indicates ultramafic rocks origin, the second other clay minerals, and the third a marine biogenic component.

\subsection{Temporal variations before industrialized era}

Temporal variations of TEs/A1, during the 1600-1850 AD period, are illustrated in figure 5. In this graphical representation, in order to remove the effect of sediment texture on TE concentrations, we have normalized TE concentrations with Al concentration. Several peaks of TE/Al ratios can be identified in relation with particular events documented on Table 4. Event 1, with small peaks of all TE/Al ratios, coincides with the very cold and long 1620-21 winter. Events 2 and 4 are related to the changes in RR channelization that occurred between Intervals I-II, and II-III (Fig. 5), respectively. In addition, Event 2 is coincidental with a Mn-rich layer (Fig. S4), that indicates an episode of abrupt sedimentation. Event 3 occurs during major inundations that have been recorded in the $1774-1777$ period (Table 4).

\subsection{Trace elements and climatic variations}

Spectral analysis carried out on data in the pre-industrial case identifies very few significant periodicities on a per-element basis. Note that this does not mean such cycles are not present, but rather reflects the fact that insufficient data are available to confidently distinguish them from noise. 
However, similarities in the spectra of elements grouped as discussed above support the grouping of elements by common origin, and are suggestive that significant peaks may be identified if additional data could be collected. In the ultramafic rocks group, for example, peaks corresponding to $65 \pm 10$ year, $21 \pm 1$ year, and $14 \pm 0.3$ year cycles line up in all three spectra (Fig. S6). The coincidence of sub-significant peaks in the clay minerals group also suggests the possibility of $65 \pm 10$ and $14 \pm 3$ year cycles (Fig. S7). Among the marine biogenic group, only the $65 \pm 10$ year cycle is coincident in all of them (Fig. S8).

Interestingly it appears that most of the frequencies here identified (i.e., 14-17, 21, 65-year cycles) correspond to the yearly mean sunspot numbers identified by Lomb (2013), including the classical decadal frequency and the Gleissberg cycles (64-110 year) for the period 1700 and 2011 AD. Also, interesting to note is that the Atlantic Multidecadal Oscillation, which govern westerly circulation in the Atlantic and influences the European climate, presents a periodicity ranging from 65 to 90 years (Knudsen et al., 2011; Olsen et al., 2012). This suggests that the oscillations in TEs of the deposited sediment on the Roustan lobe are not due to chance but reflect the climatic variations that govern drought and flood, and consequently the erosion of the catchment basin of the Rhône River. Such a process has recently been suggested to occur in the Parana delta (Milana and Kröhling, 2015), whereas Park and Chang (2013) have observed coincidence between sunspots and precipitation rhythms. Longer time series are required for verifying this hypothesis.

\subsection{Trace elements anthropization}

Data clearly show that several TE concentrations in the sediment core layer, deposited after $1850 \mathrm{AD}$, were significantly greater than those calculated for pre-industrial era. These elements show increases in mean concentrations of 3.5 times for $\mathrm{Ag}, \sim 2$ times for $\mathrm{Cd}$ and $\mathrm{Pb}$, and $\sim 1.3$ for $\mathrm{Cu}$ and $\mathrm{Zn}$, higher than the pre-industrial values. Conversely, $\mathrm{Co}, \mathrm{Cr}$, and $\mathrm{Ni}$ mean concentrations remain roughly unchanged (Table 1). A PCA, performed on post-1850 AD data, allows separation of several groups of TEs. Pristine TEs, such as $\mathrm{Co}, \mathrm{Cr}$, and $\mathrm{Ni}$, are linked with clay markers ( $\mathrm{Al}, \mathrm{Li}$ and $\mathrm{Fe}$ ), $\mathrm{Cr}$ and $\mathrm{Ni}$ being associated with $\mathrm{Mn}$, whereas $\mathrm{Cr}$ is correlated with $\mathrm{Fe}$. Another group consists of "anthropogenically impacted" elements ( $\mathrm{Ag}, \mathrm{Cd}, \mathrm{Cu}, \mathrm{Pb}$, and $\mathrm{Zn})$, within which $\mathrm{Ag}$ is correlated with $\mathrm{C}_{\text {org }}$ (Table 3b, Fig. S5b). Stable isotopic compositions of $\mathrm{Pb}$ shows highly significant $(\mathrm{p}<0.01)$ differences $(1.196 \pm 0.003$ vs $1.1843 \pm 0.004$ for 206/207 ratios (Table 1$)$. These results clearly indicate that recent sediments deposited in the Roustan lobe are contaminated 
with $\mathrm{Ag}, \mathrm{Cd}, \mathrm{Cu}, \mathrm{Pb}$ and $\mathrm{Zn}$, and have been for at least 150 years. This conclusion, which is consistent with the RR as the main source of TE contamination in the Gulf of Lions sediments (e.g., Roussiez et al., 2005, 2006; Radakovitch et al., 2008; Cossa et al., 2014), can reasonably be extended to the whole of the Rhône pro-delta sediments.

\subsection{Chronology of TE accumulation during the industrialized era}

Nine peak-events (Table 4) were recorded in the TE/Al chronological profiles (Fig. 6). Event 5, occurring during Interval III, is enriched with TEs having an anthropogenic component $(\mathrm{Ag}, \mathrm{Pb}$ and $\mathrm{Zn}$ ), and is coincidental with the 1889-91 AD period of high flooding. Event 6 is a typical Mnenriched peak, associated with $\mathrm{Co}, \mathrm{Ni}$, and $\mathrm{Cd}$, relict of the SWI exiting before the re-opening of the Roustan channel, which brought new river sediments to the KS57 site on the prodelta lobe. Also noteworthy is the $\mathrm{Co}$ and $\mathrm{Ni}$ association with $\mathrm{Mn}$, which is a common feature present at the SWIs (Goldberg, 1954; März et al., 2011; Frierdich and Catalano, 2012). Events 7-8 correspond to significant inputs of anthropic TEs, which may be related to the December 1926, November 1944 AD, February 1945 AD and November 1963 AD floods (Table 4). Trace element contamination increased dramatically after the II ${ }^{\text {nd }}$ World War and peaked around 1977 (Fig. 6). The occurrence of TE concentration maxima between 1960 and 1980 AD is a common chronological feature in Europe, in North America and, even further, in the contaminated aquatic sediments of the entire Northern hemisphere (in review by Callender, 2003). Several authors suggested that coal burning is the reason for this temporal pattern (e.g., Muller et al., 1977 cited by Callender, 2003). In areas neighboring the Rhône basin, coal burning and smelters influence has been shown for $\mathrm{Pb}$ in the Geneva Lake sediments (Monna et al., 1998), and in some Gulf of Lions canyons and PierreBlanche lagoon (Miralles et al., 2006a; Elbaz-Poulichet et al., 2011; Cossa et al., 2014). Similar chronology is also observed for $\mathrm{Pb}, \mathrm{Cd}$ and $\mathrm{Zn}$ in Arctic lake sediment (Hermanson, 1991). In North America, temporal distributions of sedimentary $\mathrm{Pb}$ in sediment cores from urban reservoirs and lakes also peak between 1960 and 1980 AD (in review by Callender, 2003). The reconstructed anthropogenic Pb emissions in France also peaked between 1960 and 1980 (Ferrand et al., 1999; Miralles et al., 2006a). Compiling the TE emissions from the pre-industrialized era to 2010 AD by gathering information from various sources (Nriagu, 1979, Nriagu and Pacyna, 1988, CITEPA, 2014) we have been able to reconstruct the TE atmospheric emission changes in Europe since 1875 (Fig. 7). The temporal trends obtain for $\mathrm{Cd}, \mathrm{Cu}, \mathrm{Pb}$ and $\mathrm{Zn}$ are very consistent with the TE/Al ratio 
chronologies recorded here (Fig. 6). This result suggests that the anthropogenic TEs accumulated in the Rhône prodelta sediments are mainly from atmospheric deposition on the RR catchment area. Copper contamination in France originates mainly from copper sulfate, used as fungicides on vineyards, known as "Bordeaux mixture". This "Bordeaux mixture” is progressively replaced by Ag bullet for treating vines. Copper contamination also originates from train catenaries and brake pad erosion (CITEPA, 2014). Chromium results mainly from electrical steelworks, from foundries, and from glass production. Cadmium is a natural back product of phosphate fertilizers (Otero et al., 2005). For the most anthropogenically impacted TEs ( $\mathrm{Pb}$ and $\mathrm{Zn}$ ), it is generally thought that the origin of the anthropogenic increase of $\mathrm{Pb}$ was emissions by leaded gasoline burning and regional industry, and that the origin of the $\mathrm{Zn}$ was a combination of urban runoff and coal burning (e.g., Cossa et al., 2014).

\subsection{Lead sources}

Stable isotopic ratios of $\mathrm{Pb}$ allow examination of the origins of $\mathrm{Pb}$. Figure 8 illustrates the relationship between ${ }^{206 / 207} \mathrm{~Pb}$ and ${ }^{206 / 208} \mathrm{~Pb}$ in the core and provides comparable data to that obtained in the Cap de Creus canyon located at the western end of the Gulf of Lions (Cossa et al., 2014). Natural, industrial, and gasoline additive isotopic Pb values are also given (Ferrand et al., 1999; Miralles et al., 2006a; Komarek et al., 2008). Firstly, it appears that sediments deposited on the Roustan lobe before 1850 have isotopic ratios close to the values of natural $\mathrm{Pb}$, with values of 1.200 at the bottom of the core $(765 \mathrm{~cm}$, i.e., $\sim 1600 \mathrm{AD})$, whereas sediments deposited since $1850 \mathrm{AD}$, with ${ }^{206 / 207} \mathrm{~Pb}$ values down to 1.175 , are clearly contaminated by European gasoline $\mathrm{Pb}$ and industrial $\mathrm{Pb}$ pools (Fig. 8). Secondly, ${ }^{206 / 207} \mathrm{~Pb}$ ratios in the sediments accumulated since $2000 \mathrm{AD}$ $(0-20 \mathrm{~cm})$ are higher than in subsurface layers in the last two decades of the last century $(1.184 \pm$ 0.0017 vs $1.179 \pm 0.0023$ ). These lower values are close to those given by Ferrand et al. (1999), i.e., 1.178-1.181, for sediments collected nearby between 1983 and 1994. These observations confirm that $\mathrm{Pb}$ contamination of the $\mathrm{RR}$ particulate discharge reached a maximum at the end of the $\mathrm{XX}^{\text {th }}$ Century, but has been decreasing since the beginning of the $\mathrm{XXI}^{\text {th }}$ Century. Using a $1 / \mathrm{Pb} v{ }^{206 / 207} \mathrm{~Pb}$ model, which allows determination of the isotopic composition of pollutant lead as the intersection with the $X$-axis (e.g., Ferrand et al., 1999), we obtained statistically significant (p<0.01) Pb isotopic signatures (the end-member for $1 / \mathrm{Pb}=0$ ) of $1.183 \pm 0.002$ and $1.175 \pm 0.002$ for the pre-industrial and industrial eras, respectively. Interestingly the intercept remains 1.175 after the banning of $\mathrm{Pb}$ in 
gasoline in Europe, i.e., $2000 \mathrm{AD}$, suggesting another anthropogenic $\mathrm{Pb}$ source. Aerosols, the ${ }^{206 / 207} \mathrm{~Pb}$ ratio values of which are less radiogenic ( $<1.16$ according to Ferrand et al., 1999), certainly contribute a low value for the industrial period. However, relatively high ${ }^{206 / 208} \mathrm{~Pb}$ is associated with low ${ }^{206 / 207} \mathrm{~Pb}$ (Fig. 8) suggesting that industrial $\mathrm{Pb}$, accumulated in soils and sediments of the RR basin has been, and still remains, a massive source of $\mathrm{Pb}$ for the Roustan lobe sediment.

The shape of the ${ }^{206 / 207} \mathrm{~Pb}$ profile (Fig. 4) exhibits a decreasing trend in ratios between Interval I and II, separated by a bump between 1700 and 1740 AD. Based on sediment samples from Interval I only, we calculate a $\mathrm{Pb}$ isotopic signature (the end-member for $1 / \mathrm{Pb}=0$ ) of $1.191 \pm 0.002$, which is significantly lower $(\mathrm{p}<0.01)$ than the signature obtained for the pre-1850 AD period (see above). These features suggest (i) that an input of low radiogenic $\mathrm{Pb}$ has accompanied the flood or/and channelization change that occurred at the end of the XVII ${ }^{\text {th }}$ Century (see Event 2 on Table 4 and Fig. 5), and (ii) that $\mathrm{Pb}$ contamination slowly started a hundred years before the beginning of the $2^{\text {nd }}$ Industrial Revolution (1850 AD).

\section{Summary and Conclusions: The Rhône prodelta anthropization in the context of Mediterranean Sea}

Trace element concentrations in surface coastal sediments are largely documented in the Western Mediterranean and the Eastern Mediterranean (e.g., Scoullos and Oldfield, 1986; AbdelMoati and El-Sammak, 1997; Abi-Ghanem et al., 2009 and 2010; Schintu et al., 2009 and 2015; Mzoughi and Chouba, 2011; Roussiez et al., 2011). Concentrations range between geological backgrounds, with the example of Sardinia coasts (Schintu et al., 2009), and very high concentrations. In the case of $\mathrm{Pb}$, the increases reach up to 30 -fold increase in the sediment of Elefsis Gulf, subjected to intense anthropogenic pressures of the cities of Athens (Scoullos and Oldfield, 1986), or up to 70-fold increase in the sediment of the Manzala lagoon sediments (Nile delta), directly linked with the Greater Cairo metropolitan city (Abdel-Moati and El-Sammak, 1997).

Historical reconstructions of the anthropization are less numerous. They systematically testify temporal trends for $\mathrm{Pb}$ and $\mathrm{Zn}$ starting between 1850 and 1920 in relation with the industrialization history of each area. In some cases, the metal contamination peaks between 1950 and 1970 in 
conjunction with coal utilization (e.g., Azoury et al., 2013). In other cases, there is no evidence of any decline of the concentrations in recent years (e.g., Palanques et al., 1998 and 2008). In the Po delta sediments (Northern Adriatic Sea), most $\mathrm{Pb}$ and $\mathrm{Zn}$ concentration-depth/year profiles in cores showed an upward increase from 1860 and a still significant anthropogenic supply at the time of sampling (Romano et al., 2013). In Llobregat prodelta sediment, near the city of Barcelona, the sharpest increase in anthropogenic $\mathrm{Cu}, \mathrm{Pb}$ and $\mathrm{Zn}$ corresponds to the period 1920-1960, with 1.5 to 10-fold concentration increases (Palanques et al., 2008). In the nearby Besos prodelta sediments, the sharper increases in metal concentration also occurred in the 1920s and the 1960s, but no evidence of current reduction of the anthropogenic inputs was observed (Palanques et al., 1998). In both cases, these increases in anthropization coincide with the industrial development and population evolution in Catalonia. Similar evolution was found in Ligurian canyons sediment located near the French-Italian boundary (Martin et al., 2009 and Heimbürger et al., 2012). They contrast with the sediments of the Rhône prodelta presented here, some Gulf of Lions canyons (Miralles et al., 2006a; Cossa et al., 2014), the Pierre Blanche lagoon (Elbaz-Pouchet et al., 2011) both located within the Gulf of Lions, and even the remote Lebanon continental shelf (Azoury et al., 2013) where the sedimentations rates are high enough to point out that anthropization has reached maxima within the second half of the $\mathrm{XX}^{\text {th }}$ Century.

Here, we show that Rhône River prodeltaic prism has archived riverine and marine sedimentary inputs for the last 4 centuries. During the pre-industrialized era (i.e., before 1850 AD) TEs concentrations (with the exception of $\mathrm{Cr}$ ) were no different from the average composition of Earth's upper crust. Three origins for TEs were identified: (i) ultramafic rocks ( $\mathrm{Li}, \mathrm{Cr}, \mathrm{Ni}$ ), (ii) other clay minerals ( $\mathrm{Co}, \mathrm{Cu}, \mathrm{Pb}$, and $\mathrm{Zn}$ ), and (iii) marine biogenic matter (Ag, Cd). During the pre-industrial period, several peaks in the TEs/Al ratios coincided with flood events or/and changes in the channelization of the Rhône River mouth. In addition, frequency analysis using Lomb-Scargle Periodograms is suggestive that some oscillations in TEs of the deposited sediment reflect climatic variations, such as the Atlantic Multidecadal Oscillation, that ultimately govern water precipitations and consequently the erosion of the catchment basin of the Rhône River.

Sediment deposited after $1850 \mathrm{AD}$ has some TE concentrations exceeding up to 3.5 times those of the pre-industrial era $(\mathrm{Ag}>\mathrm{Cd}-\mathrm{Pb}>\mathrm{Cu}-\mathrm{Zn})$. Principal Component Analyses allows identification of two groups of TEs during the industrialized era: (i) Pristine TEs, such as Co, Cr, and Ni, are linked with clay markers (Al, $\mathrm{Li}$ and Fe), and (ii) "Anthropogenically impacted" TEs (Ag, Cd, Cu, 
$\mathrm{Pb}$, and $\mathrm{Zn}$ ). TE contamination increased dramatically after the Second World War and reached a maximum between 1970 and 1980, consistently with atmospheric emissions changes.

\section{Acknowledgements}

We thank the scientific team as well as the captain and crew of the cruise RHOSOS-2008 cruise on board R/V Le Suroît. This study was carried out as a part of the WP3 MERMEX/MISTRALS and is a contribution to the international LOICZ projects. This work was partly supported by the European project HERMIONE (FP7-ENV-2008-1-226354) and ANR EXTREMA (contract number ANR-06-VULN-005). We are grateful to O. Radakovich for his comments on the manuscript.

\section{References}

Abi-Ghanem, C., Chiffoleau, J.-F., Bermond, A., Nakhlé, K., Khalaf, G., Borschneck D., Cossa. D. 2009. Lead and its Isotopes in the Sediment of three Sites on the Lebanese Coast: Identification of Contamination Sources and Mobility. Applied Geochemistry, 24, 1990-1999.

Abi-Ghanem, C., Nakhlé, K., Khalaf, G., Cossa, D. 2010. Mercury distribution and methylmercury mobility in the sediments of three sites on the Lebanese coast, Eastern Mediterranean. Archives of Environmental Contamination and Toxicology, DOI 10.1007/s00244-010-9555-9.

Abdel-Moati, M.A.R., El-Sammak, A.A. 1997. Man-made impact on the geochemistry of the Nile Delta lakes. A study of metals concentrations in sediments. Water Air \& Soil Pollution, 97, 413-419.

Amorosi, A. 2012. Chromium and nickel as indicators of source-to-sink sediment transfer in a Holocene alluvial and coastal system (Po, Italy). Sedimentary Geology, 280, Special Issue, 260-269.

Antonelli, C., Provansal, M., Vella, C. 2004. Recent morphological channel changes in a deltaic environment. The case of the Rhône River, France. Geomorphology, 57, 385-402. 
Antonelli, C., Eyrolle, F., Rolland, B., Provansal, M., Sabatier, F. 2008. Suspended sediment and ${ }^{137}$ Cs fluxes during the exceptional December 2003 flood in the Rhône River, southeast France. Geomorphology, 95, 350-360.

Arnaud-Fassetta, G. 1998. Dynamiques fluviales holocènes dans le delta du Rhône. UFR des Sciences Géographiques. Université de Provence, Aix en Provence, p. 329.

Arnaud-Fassetta, G. 2003. River channel changes in the Rhône Delta (France) since the end of the Little Ice Age: geomorphological adjustment to hydroclimatic change and natural resource management. Catena, 51, 141-172.

Association Nazairienne de Généalogie. Epidémies et famines en France : Climat et épidémie. http://angeneasn.free.fr/epidemies.htm

Azoury, S., Tronczyński, J., Chiffoleau, J.-F., Cossa, D., Nakhle, K., Khalaf, G. 2013. Historical records of $\mathrm{Hg}, \mathrm{Pb}$ and $\mathrm{PAH}$ depositions in a dated sediment core from the Eastern Mediterranean. Environmental Science \& Technology, 47, 7101-7109.

Burdige, D.J., Gieskes, J.M. 1983. A pore water/solid phase diagenetic model for manganese in marine sediments. American Journal Science, 283, 29-47.

Callender, E. 2003. Heavy Metals in the Environment-Historical Trends. Chap. 9.03, In: Treatise on Geochemistry, Vol. 9, Holland, H. \& K.K. Turekian editors, Elsevier Ltd. pp 67-105.

Calmet, D., Fernandez, J.-M. 1990. Caesium distribution in northwest Mediterranean seawater, suspended particles and sediments. Continental Shelf Research, 10, 895-913.

Cathalot, C., Rabouille, C., Pastor, L., Deflandre, B., Viollier, E., Buscail, R., Grémare, A. Treignier, C., Pruski, A. 2010. Temporal variability of carbon recycling in coastal sediments influenced by rivers: assessing the impact of flood inputs in the Rhône River prodelta. Biogeosciences, 7, 1187-1205.

Cauwet, G., Gadel, F., De Souza Sierra, M.M., Donard, O., Ewald, M. 1990. Contribution of the Rhône river to organic inputs to the northwestern Mediterranean Sea. Continental Shelf Research, 10, 1025-1037.

Champion, M. 1862. Les inondations en France depuis le VIe siècle jusqu'à nos jours. Vol. 4, Chap. XXIV. Dunod éditeur, Paris. 126p. 
Charmasson, S., Radakovitch, O., Arnaud, M., Bouisset, P., Pruchon, A. 1998. Long-cores profiles of 137Cs, 134Cs, 60Co and 210Pb in sediment near the Rhône River (Northwestern Mediterranean Sea). Estuaries, 21, 367-378.

Chiffoleau, J.F., Auger, D., Boutier, B., Rozuel, E., Truquet, I. 2004. Dosage de certains métaux dans les sédiments et la matière en suspension par absorption atomique. Méthodes d'Analyses en milieu marin, Editions Ifremer, BP 70, F-29280 Plouzané (ISSN 1637-1844).

CITEPA, 2014. http://www.citepa.org/fr/air-et-climat/polluants/metaux-lourds/cuivre.

Colley, S., Thomson, J., Wilson, T.R.S., Higgs, N.C. 1984. Post-depositional migration of elements during diagenesis in brown clays and turbidite sequences in the Northeast Atlantic. Geochimica et Cosmochimica Acta, 48, 1223-1236.

Compagnie Générale du Rhône. http://www.ecologie-et-progres.com/crue.htm

Cossa, D., Buscail, R. Puig, P., Chiffoleau, J.-F., Radakovitch, O., Jeanty, G., Heussner, S. 2014. Origin and accumulation of trace elements in sediments of the northwestern Mediterranean margin. Chemical Geology, 380, 61-73.

Deflandre, B., Mucci, A., Gagné, J.-P., Guignard, C., Sundby, B. 2002. Early diagenetic processes in coastal marine sediments disturbed by a catastrophic sedimentation event. Geochimica et Cosmochimica Acta, 66, 2547-2558.

Elbaz-Poulichet, F., Dezileau, L., Freydier, R., Cossa, D., Sabatier, P. 2011. A 3500-year record of $\mathrm{Hg}$ and $\mathrm{Pb}$ contamination in a Mediterranean sedimentary archive (the Pierre Blanche Lagoon, France). Environmental Science \& Technology, 45, 8642-8647.

Emerson, S., Bender, M. 1981. Carbon fluxes at the sediment-water interface of the deep-sea: calcium carbonate preservation. Journal of Marine Research, 39, 139-162

Eyrolle, F., Duffa, C., Antonelli, C., Rolland, B., Leprieur, F. 2006. Radiological consequences of the extreme flooding on the lower course of the Rhône valley (December 2003, South East France). Science of the Total Environment, 366, 427-438.

Fanget, S., Bassetti, M.-A., Arnaud, M., Chiffoleau, J.-F., Cossa, D., Goineau, A. Fontanier, C., Buscail, R., Jouet, G., Maillet, G.M., Negri, A. Dennielou, B., Berné, S. 2013. Historical 
evolution and extreme climate events during the last 400 years on the Rhône prodelta (NW Mediterranean). Marine Geology, 346, 375-391.

Ferrand, J.-L., Hamelin, B., Monaco, A. 1999. Isotopic tracing of anthropogenic Pb inventories and sedimentary fluxes in the Gulf of Lions (NW Mediterranean Sea). Continental Shelf Research, $19,23-47$.

Fournet, V. 2012. Crue de l'Ouvèze (affluent de la rive gauche du Rhône). http://www.les-sorguesvertes.com/uploaded/au-fil-du-temps-au-fil-de-leau-20-12-12.pdf. Page 7.

Frierdich, A.J., Catalano, J.G. 2012. Distribution and speciation of trace elements in iron and manganese oxide cave deposits. Geochimica et Cosmochimica Acta, 91, 240-253.

Gadde R.R., Laitinen, H.A. 1974. Heavy metal adsorption by hydrous iron and manganese oxides. Analytical Chemistry, 46, 2022-2026.

Gairoard, S., Radakovitch, O., Eyrolle, F., Ludwig, W., Cossa, D. 2012. Flux de matière solides et liquides des bassins versants français à la Mer Méditerranée : État des connaissances et recommandations pour un suivi optimisé. Publication CEREGE pour 1'AERMC. Sept. 2012.

García-García, A., Orange, D., Lorenson, T., Radakovitch, O. Tesi, T., Miserocchi, S., Berné, S., Friend, P.1., Nittrouer, C., Normand, A. 2006. Shallow gas off the Rhône prodelta, Gulf of Lions. Marine Geology, 234, 215-231.

Goldberg, E.D. 1954. Marine geochemistry 1. Chemical scavengers of the sea. Journal of Geology, $62,249-265$.

Heimbürger, L.-E., Cossa, D., Thibodeau, B., Khripounoff, A., Mas, V., Chiffoleau, J.-F., Schmidt, S., Migon, C. 2012. Natural and anthropogenic trace metals in sediments of the Ligurian Sea (Northwestern Mediterranean). Chemical Geology, 291, 141-151.

Hermanson, M.H. 1991. Chronology and Sources of Anthropogenic Trace Metals in Sediments from Small, Shallow Artic Lakes. Environmental Science \& Technology, 25, 2059-2064.

Huang, J., Deokchoi, H., Hopke, P., Holsen, T. 2010. Ambient mercury sources in Rochester, NY: results from Principle components analysis (PCA) of mercury monitoring network data. Environmental Science \& Technology, 44, 8441-8445. 
Jackson, J.E., 1991. A User's Guide to Principal Components. Wiley Series in Probability and Statistics, J. Wiley and Sons (592 pages).

Kuzyk, Z.Z.A., Macdonald, R.W., Stern, G.A., Gobeil, C. 2011. Inferences about the modern organic carbon cycle from diagenesis of redox-sensitive elements in Hudson Bay. Journal of Marine Systems, 88, 451-462.

Komarek, M., Ettler, V., Chrastny, V., Mihaljevic, M., 2008. Lead isotopes in environmental sciences: a review. Environment International, 34, 562-577.

Kersten, M., Smedes, F. 2002. Normalization procedures for sediment contaminants in spatial and temporal trend monitoring. Journal of Environmental Monitoring, 4, 109-115.

Knudsen, M.F., M.-S. Seidenkrantz, B.H. Jacobsen, A. Kuijpers. 2011. Tracking the Atlantic Multidecadal Oscillation through the last 8,000 years. Nature Communication, 2, 178-181.

Launay, M. 2014. Flux de contaminants particulaires dans un grand cours d'eau anthropisé : dynamique des PCB et du mercure transportés par les matières en suspension du Rhône, du Léman à la Méditerranée. Thèse de doctorat de l’Université de Lyon. France.

Li, Y.-H. 2000. A compendium of geochemistry: from solar nebula to human brain. Princeton University Press, Princeton, New Jersey, ISBN 0-691-00938-4.

Lomb, N. 2013. The sunspot cycle revisited. Journal of Physics: Conference Series, 440012042. IOP Publishing. doi:10.1088/1742-6596/440/1/012042.

Loring, D.H. 1991. Normalization of heavy-metal data from estuarine and coastal sediments. ICES Journal of Marine Science, 48, 101-115.

Loring, D.H., Rantala, R.T.T., 1990. Sediments and suspended particulate matter: total and partial methods of digestion. ICES Techniques in Marine Environmental Sciences $N^{\circ} 9$ (14 pp.).

Maillet, G.M., Vella, C., Provansal, M., Sabatier, F. 2006a. Connexions entre le Rhône et son delta (partie 2) : évolution de l'embouchure du Rhône depuis le début du XVIII ${ }^{\mathrm{e}}$ siècle.

Géomorphologie : Relief, Processus, Environnement, 2, 125-140.

Maillet, G.M., Vella, C., Berne, S., Friend, P.L., Amos, C.L., Fleury, T.J., Normand, A. $2006 b$. Morphological changes and sedimentary processes induced by the December 2003 flood event 
at the present mouth of the Grand Rhône River (southern France). Marine Geology, 234, 159177.

Martin, J., Sanchez-Cabeza, J.A., Eriksson, M., Levy, I., Miquel, J.-C. 2009. Recent accumulation of trace metals in sediments at the DYFAMED site (Northwestern Mediterranean Sea). Marine Pollution Bulletin, 59, 146-153.

März, C., Stratmann, A., Matthiessen, J., Meinhardt, A.-K., Eckert, S., Schnetger, B., Vogt, C., Stein, R., Brumsack, H.-J. 2011. Manganese-rich brown layers in Arctic Ocean sediments: Composition, formation mechanisms, and diagenetic overprint. Geochimica et Cosmochimica Acta, 75, 7668-7687.

Migon, C., Sandroni, V., Marty, J.-C., Gasser, B., Miquel, J.-C. 2002. Transfer of atmospheric matter through the euphotic layer in the northwestern Mediterranean: seasonal pattern and driving forces. Deep Sea Research Part I, 49, 2125-2141.

Milana, J.P., Kröhling, D. 2015. Climate changes and solar cycles recorded at the Holocene Paraná Delta, and their impact on human population. Scientific Reports, 5, Article number: 12851.

Miralles, J., Radakovitch, O., Aloisi, J.-C. $2005 .{ }^{210} \mathrm{~Pb}$ sedimentation rates from the Northwestern Mediterranean margin. Marine Geology, 261, 155-167.

Miralles, J. Véron, A.J., Radakovitch, O., Deschamps, P., Tremblay, T. Hamelin, B. $2006 a$. Atmospheric lead fallout over the last century recorded in Gulf of Lions sediments (Mediterranean Sea). Marine Pollution Bulletin, 52, 1364-1371.

Miralles, J., Arnaud, M., Radakovitch, O., Marion, C., Cagnat, X. 2006b. Radionuclide deposition in the Rhône River Prodelta (NW Mediterranean Sea) in response to the December 2003 extreme flood. Marine Geology, 234, 179-189.

Monna, F., Dominik, J., Loizeau, J.-L., Arpagaus, P., Piccard, J. 1998. High resolution lead-isotope record in Lake Geneva (Switzerland-France). Mineralogical Magazine 62A, 1010-1012.

Mucci, A. 1983. The solubility of calcite and aragonite in seawater at various salinities, temperature, and one atmosphere total pressure. American Journal of Science, 283, 780-799. 
Muller, G., Grimmer, G., Bohnke, H. 1977. Sedimentary record of heavy metals and polycyclic aromatic hydrocarbons in Lake Constance. Naturwissenschaften, 64, 427-431.

Mzoughi, N., Chouba, L. 2011. Distribution of trace metals, aliphatic hydrocarbons and polycyclic aromatic hydrocarbons in sediment cores from the Sicily Channel and the Gulf of Tunis (southwestern Mediterranean Sea). Environmental Technology, 32, 43-54.

Nriagu, J.O. 1979. Global inventory of natural and anthropogenic emissions of trace metals to the atmosphere. Nature, 279, 409-411.

Nriagu, J.O., Pacyna, J.M. 1988. Quantitative assessment of worldwide contamination of air, water and soils by trace metals. Nature, 333, 134-139.

Olsen, J., Anderson, N.J., Knudsen, M.F. 2012. Variability of the North Atlantic Oscillation over the past 5,200 years. Nature Geoscience, 5, 808-812.

Otero, N., Vitoria, L., Soler, A., Canals, A. 2005. Fertilizer characterization: major trace and rare earth elements. Applied Geochemistry, 20, 1473-1488.

Palanques, A., Sanchez-Cabeza, J.A., Masque, P., Leon, L. 1998. Historical record of heavy metals in a highly contaminated Mediterranean deposit: The Besos prodelta. Marine Chemistry, 61, 209-217.

Palanques, A., Masque, P., Puig, P., Sanchez-Cabeza, J.A., Frignani, M., Alvisi, F. 2008. Anthropogenic trace metals in the sedimentary record of the Llobregat continental shelf and adjacent Foix Submarine Canyon (northwestern Mediterranean). Marine Geology, 248, 213217.

Pardé, M. 1928. Les crues du Rhône en décembre 1925 et février 1928. Les Etudes rhodaniennes, $4(4), 3-46$.

Pardé, M. 1948. Les crues du Rhône de novembre 1944 à février 1945. Les Etudes rhodaniennes 23(23-1), 69-76.

Park, J.-H., Chang, H.-Y. 2013. Drought over Seoul and Its Association with Solar Cycles. Journal of astronomy and space sciences, 30, 241-246.

Pichard, G. 1995. Les crues sur le bas Rhône de 1500 à nos jours. Pour une histoire hydroclimatique. In : Méditerranée, Tome 82, 3-4-1995. Les origines de Marseille. Environnement et 
archéologie. pp. 105-116. http://www.persee.fr/web/revues/home/prescript/article/medit_ 0025-8296_1995_num_82_3_2908

Pont, D., Simonnet, J.P., Walter, A.V. 2002. Medium-term changes in suspended sediment delivery to the ocean: consequences of catchment heterogeneity and river management (Rhône River, France). Estuarine \& Costal Shelf Science, 54, 1-18.

Provansal, M., Vella, C., Arnaud-Fassetta, G., Sabatier, F., Maillet, G. 2003. Role of fluvial sediment inputs in the mobillity of the Rhône delata coast (France). Géomorphologie : reliefs, processus, environnement, 4, 271-282.

Provansal, M., Dufour, S., Sabatier, F., Anthony, E. J., Raccasi, G., Robresco, S. 2014. The geomorphic evolution and sediment balance of the lower Rhône River (southern France) over the last 130 years: Hydropower dams versus other control factors. Geomorphology, 219, $27-41$.

Radakovitch, O., Charmasson, S., Arnaud, M., Bouisset, P. 1999. ${ }^{210} \mathrm{~Pb}$ and caesium accumulation in the Rhône delta sediments. Estuarine \& Costal Shelf Science, 48, 77-92.

Radakovitch, O, Roussiez, V., Ollivier, P., Ludwig, W., Grenz, C., Probst, J.-L. 2008. Input of particulate heavy metals from rivers and associated sedimentary deposits on the Gulf of Lion continental shelf. Estuarine \& Costal Shelf Science, 77, 285-295.

Rassmann, J., Lansard, B., Pozzato, L., Rabouille, C. 2016. Carbonate chemistry in sediment pore waters of the Rhône River delta driven by early diagenesis (NW Mediterranean).

Biogeosciences, Discuss., doi:10.5194/bg-2016-212.

Robbins, J.A. 1978. Geochemical and geophysical applications of radioactive lead isotopes. In: Nriagu, J.P. (Ed.), Biogeochemistry of Lead, pp. 285-393. North-Holland, Amsterdam.

Romano, S., Langone, L., Frignani, M., Albertazzi, S., Focaccia, P., Bellucci, L.G., Ravaioli, M. 2013. Historical pattern and mass balance of trace metals in sediments of the northwestern Adriatic Sea Shelf. Marine Pollution Bulletin, 76, 32-41.

Roussiez, V., Ludwig, W., Probst, J.-L., Monaco, A. 2005. Background levels of heavy metals in surficial sediments of the Gulf of Lions (NW Mediterranean Sea): an approach based on ${ }^{133} \mathrm{Cs}$ normalization and lead isotope measurements. Environmental Pollution, 138, 167-177. 
Roussiez, V., Ludwig, W., Monaco, A., Probst, J.-L., Bouloubassi, I., Buscail, R., Saragoni, G. 2006. Sources and sinks of sediment-bound contaminants in the Gulf of Lions (NW Mediterranean Sea): a multi-tracer approach. Continental Shelf Research, 26, 1843-11857.

Roussiez, V., Ludwig, W., Radakovitch, O., Probst, J.-L., Monaco, A., Charrière, B., Buscail, R. 2011. Fate of metals in coastal sediments of a Mediterranean flood-dominated system: An approach based on total and labile fractions. Estuarine \& Costal Shelf Science, 92, 486-495.

Sabatier, F., Maillet, G., Provansal, M., Fleury, T.-J., Suanez, S., Vella, C. 2006. Sediment budget of the Rhône delta shoreface since the middle of the 19th century. Marine Geology, 234, 143157.

Santschi, P.H., Presley, B.J., Wade, T.L., Garcia-Romero B., Baskaran, M. 2001. Historical contamination of PAHs, PCBs, DDTs, and heavy metals in Mississippi River Delta, Galveston Bay and Tampa Bay sediment cores. Marine Environmental Research, 52, 51-79.

Schintu, M., Marras, B., Maccioni, A., Puddu, D., Meloni, P., Contu, A. 2009. Monitoring of trace metals in coastal sediments from sites around Sardinia, Western Mediterranean. Marine Pollution Bulletin, 58, 1577-1583.

Schintu, M., Buosi, C., Galgani, F., Marrucci, A., Marras, B., Ibba, A., Cherchi, A. 2015. Interpretation of coastal sediment quality based on trace metal and PAH analysis, benthic foraminifera, and toxicity tests (Sardinia, Western Mediterranean). Marine Pollution Bulletin, $94,72-83$.

Scoullos, M.J., Oldfield, F. 1986. Trace metal and magnetic studies of sediments in Greek estuaries and enclosed gulfs. Marine Chemistry, 18, 249-268.

The Mermex Group: Durrieu de Madron, X., Guieu, C., Sempéré, R., Conan, P., Cossa, D., et al. 2011. Marine ecosystems' responses to climatic and anthropogenic forcings in the Mediterranean. Progress in Oceanography, 91, 97-166.

Valette-Silver, N.J. 1993. The use of sediment cores to reconstruct historical trends in contamination in estuarine and coastal sediments. Estuaries 16(3B), 577-588.

Windom, H.L., Schropp, S.J., Calder, F.D., Ryan, J.D., Smith Jr., R.G., Burney, L.C., Lewis, F.G., Rawlinsori, C.H. 1989. Natural trace metal concentrations in estuarine and coastal marine 
sediments of the southeastern United States. Environmental Science \& Technology, 23, 314320. 


\section{Figure captions}

Fig. 1. Detailed morphology of the Rhône subaqueous delta and main onshore morpho-sedimentary features from Fanget et al. (2013).

Fig. 2. Iron (Fe), Aluminium (Al) and lithium (Li) vertical profiles in sediment core KS57 during the last 400 years.

Fig. 3. Organic carbon $\left(\mathrm{C}_{\text {org }}\right)$ vertical profiles in sediment core KS57 during the last 400 years.

Fig. 4. Lead $(\mathrm{Pb})$ stable isotope ratios vertical profiles in sediment core KS57 during the last 400 years.

Fig. 5. Trace element (TEs) vertical profiles in sediment core KS57 during the last 400 years.

Fig. 6. Trace element (TEs) vertical profiles in sediment core KS57 during the industrialized era.

Fig. 7. Trace element (TEs) emission increase in Europe relatively to the year 1875 AD. Diagram built from Nriagu (1979), Nriagu and Pacyna (1988) and CITEPA (http://www.citepa.org/).

Fig. 8. ${ }^{206 / 207} \mathrm{~Pb} v{ }^{206 / 208} \mathrm{~Pb}$ relationships in sediment core KS57 before and after 1850 AD. Equivalent data from the Cap de Creus (CdC) sediments (from Cossa et al., 2014) are given for comparison. 


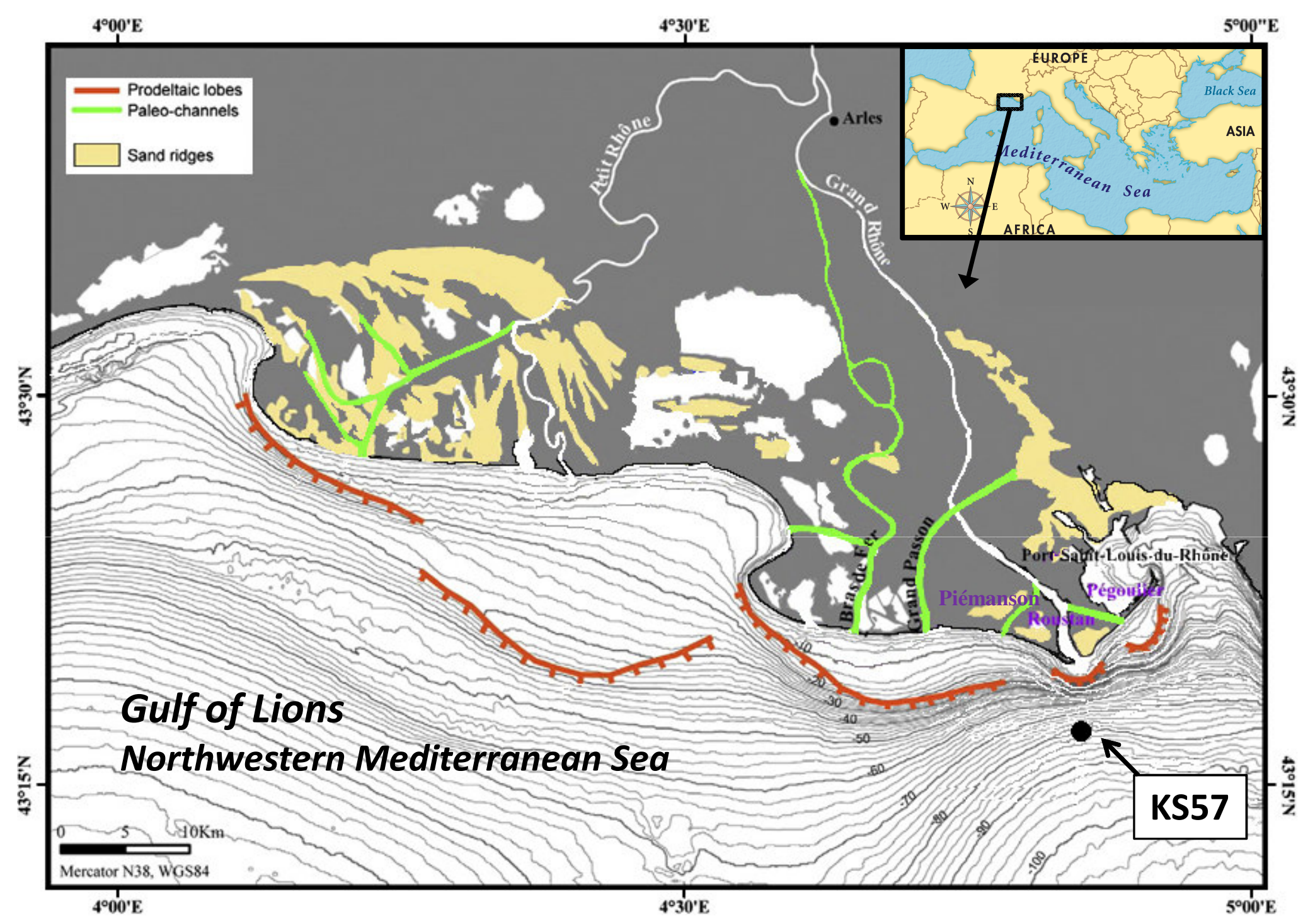

Fig. 1 

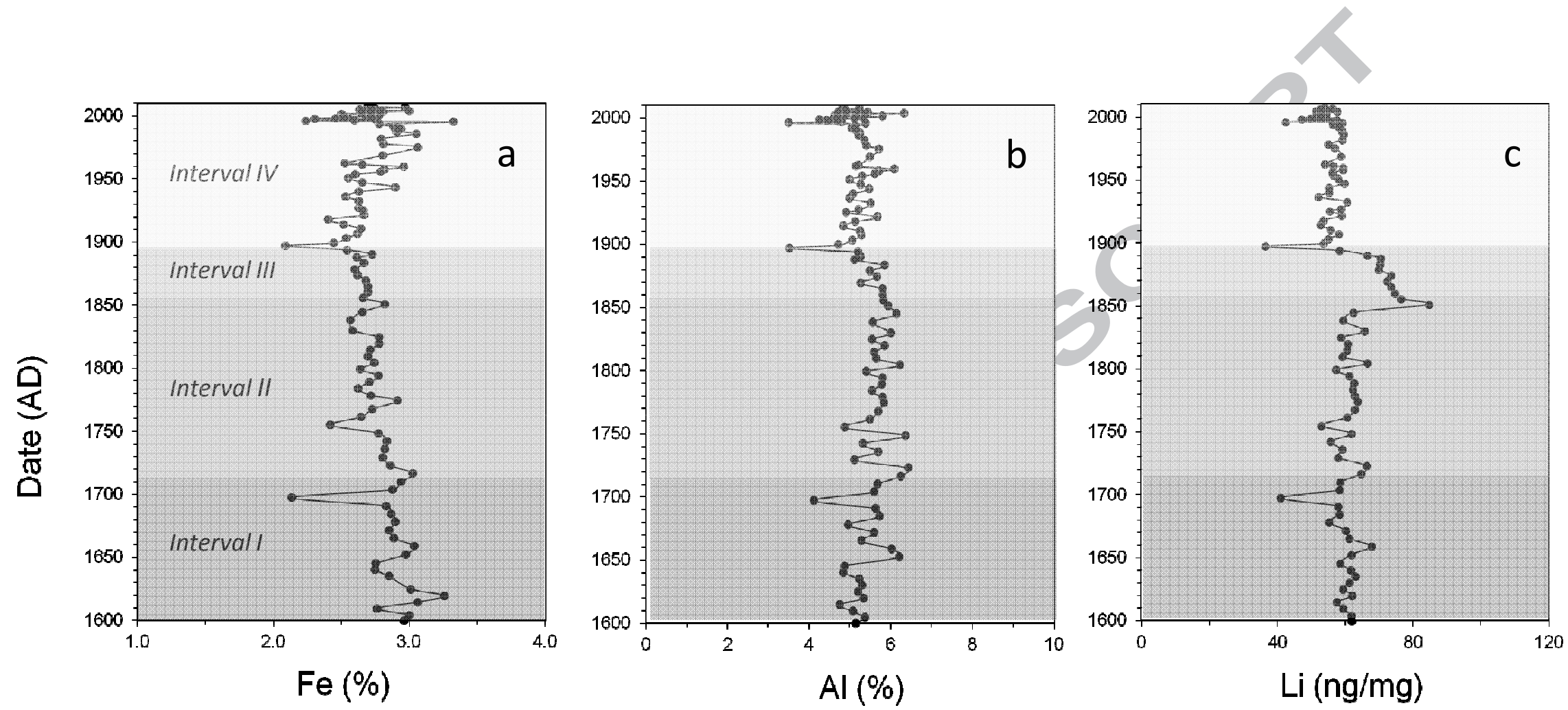

Fig. 2 


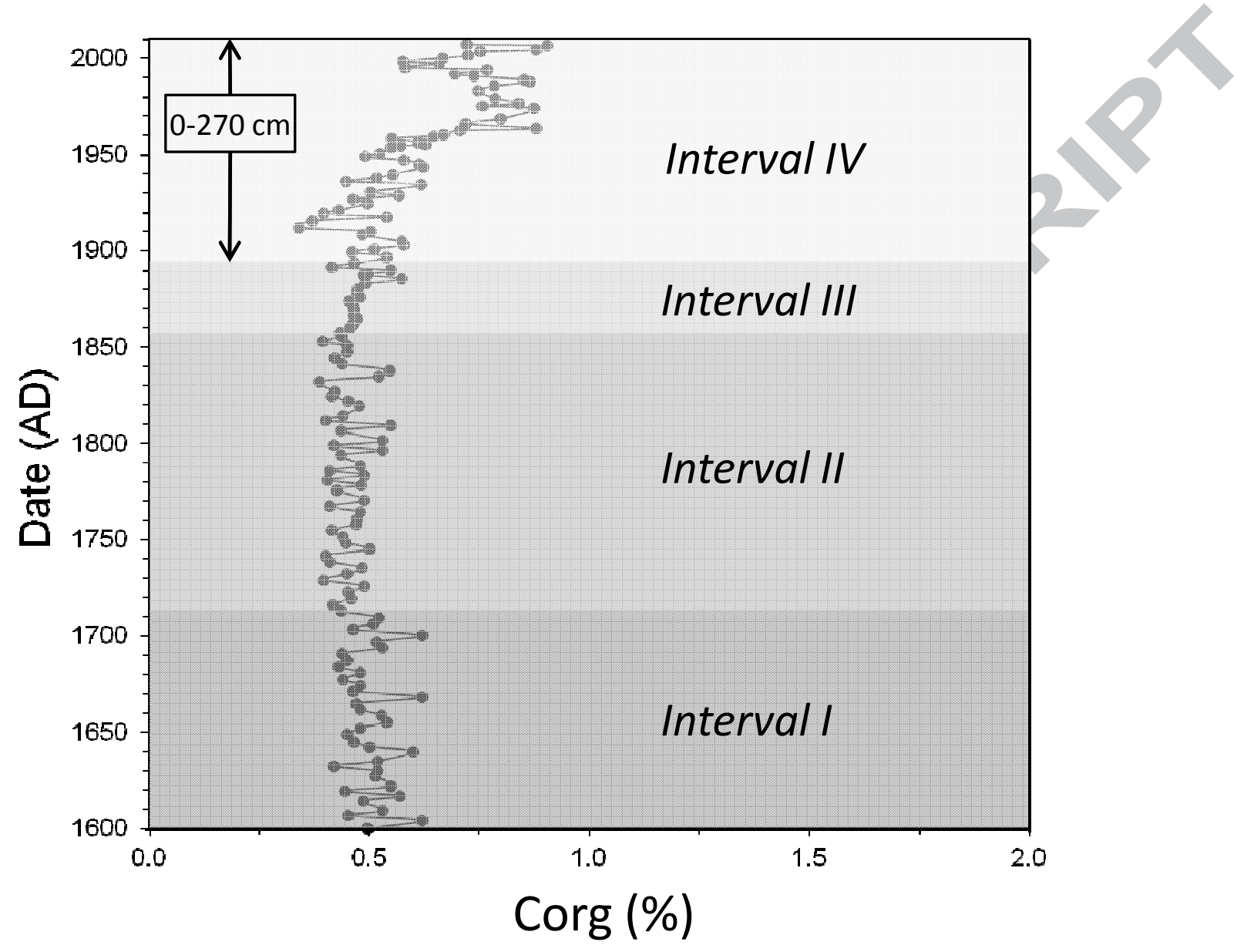

Fig. 3 

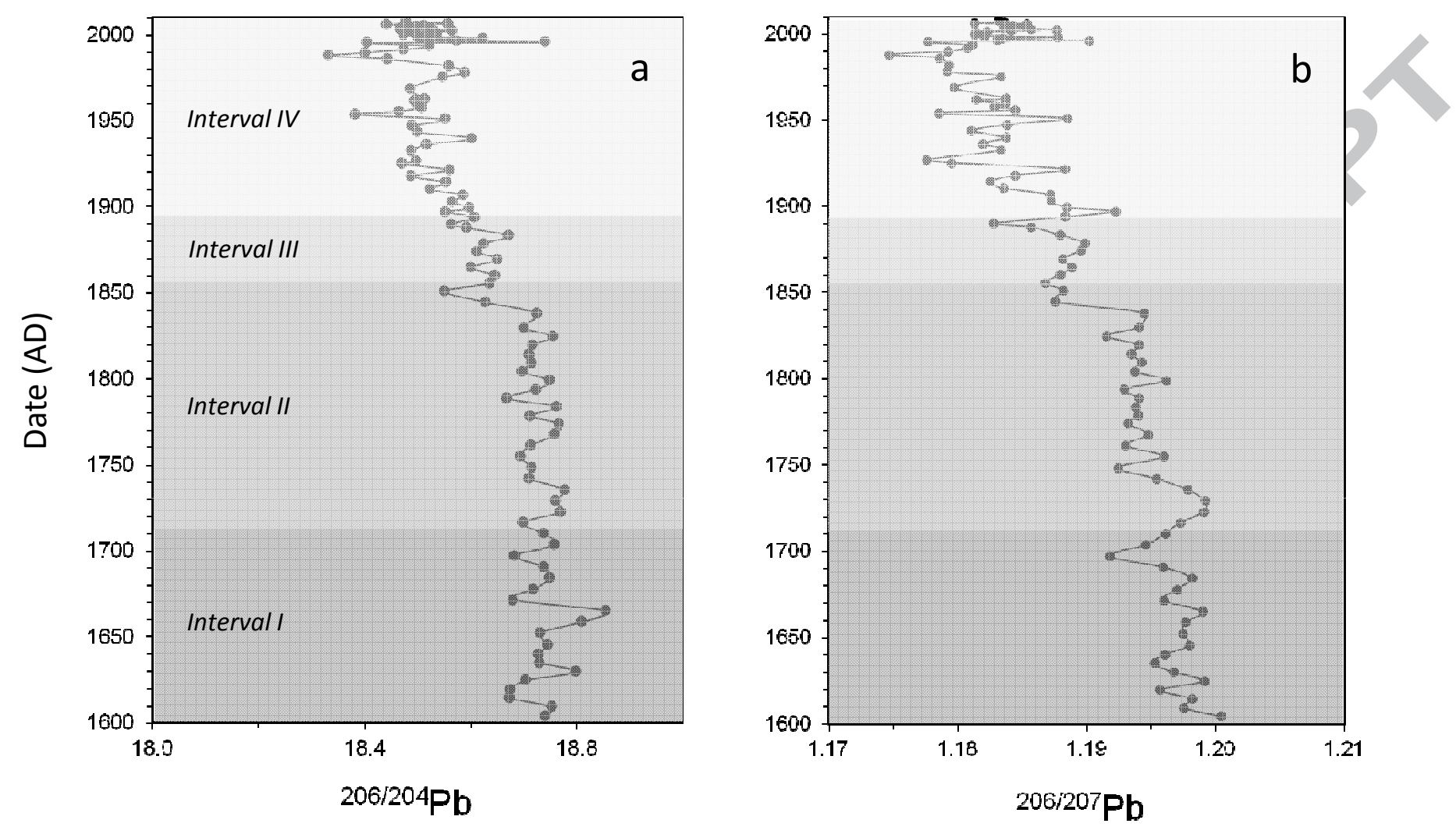

Fig. 4 

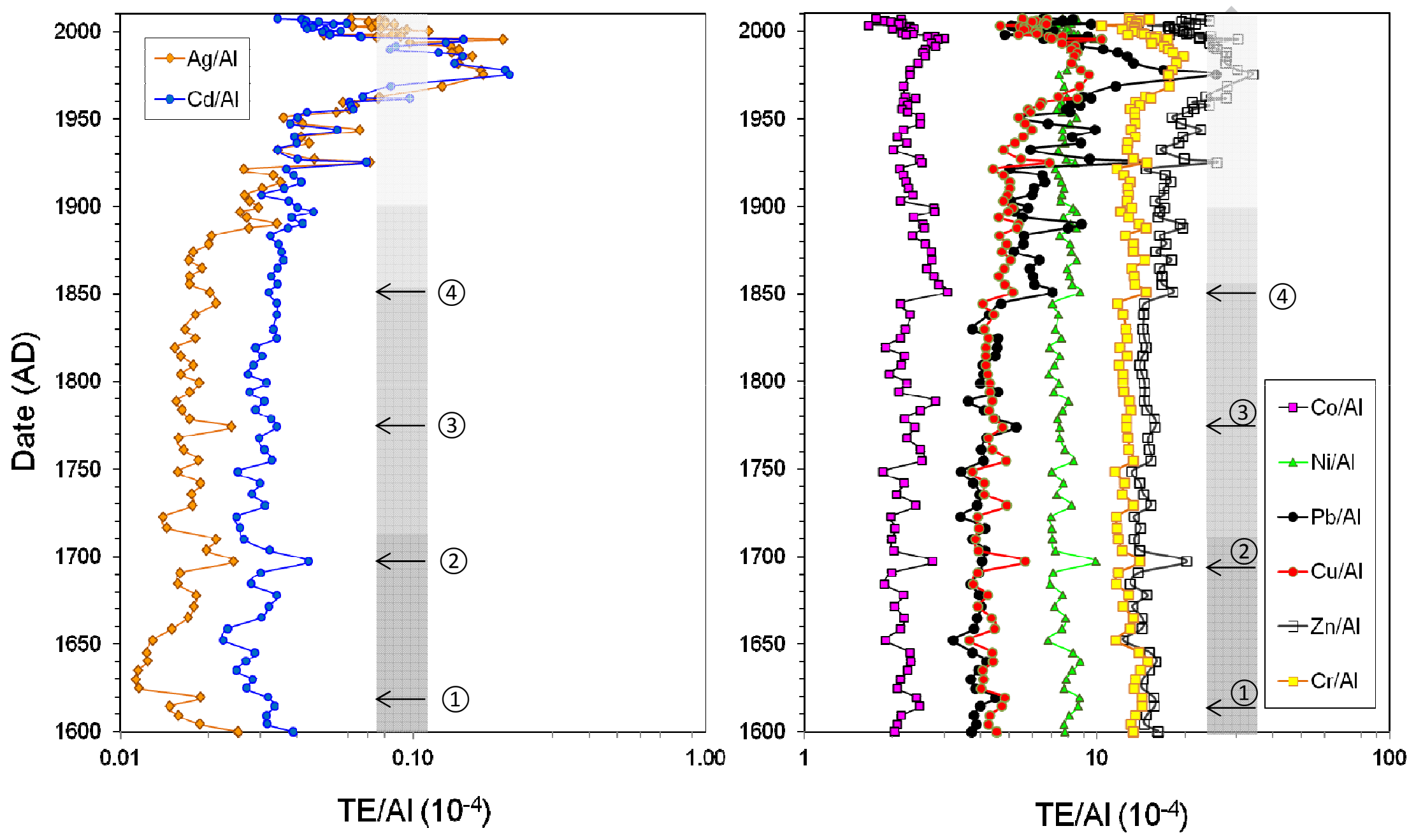

Fig. 5 

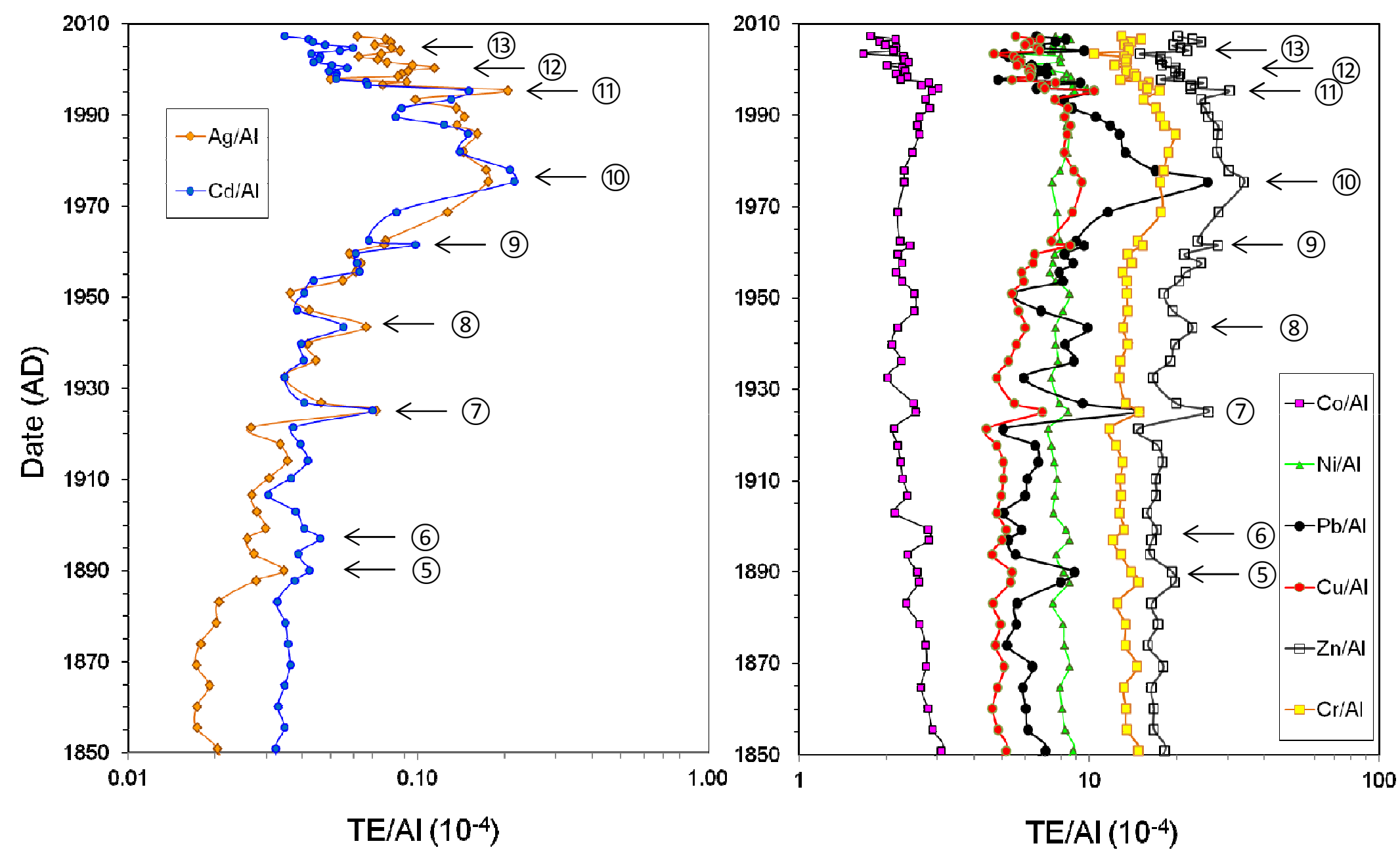

Fig. 6 
$\frac{T}{09}$

Emission increase since 1875 AD (Mg yr-1)

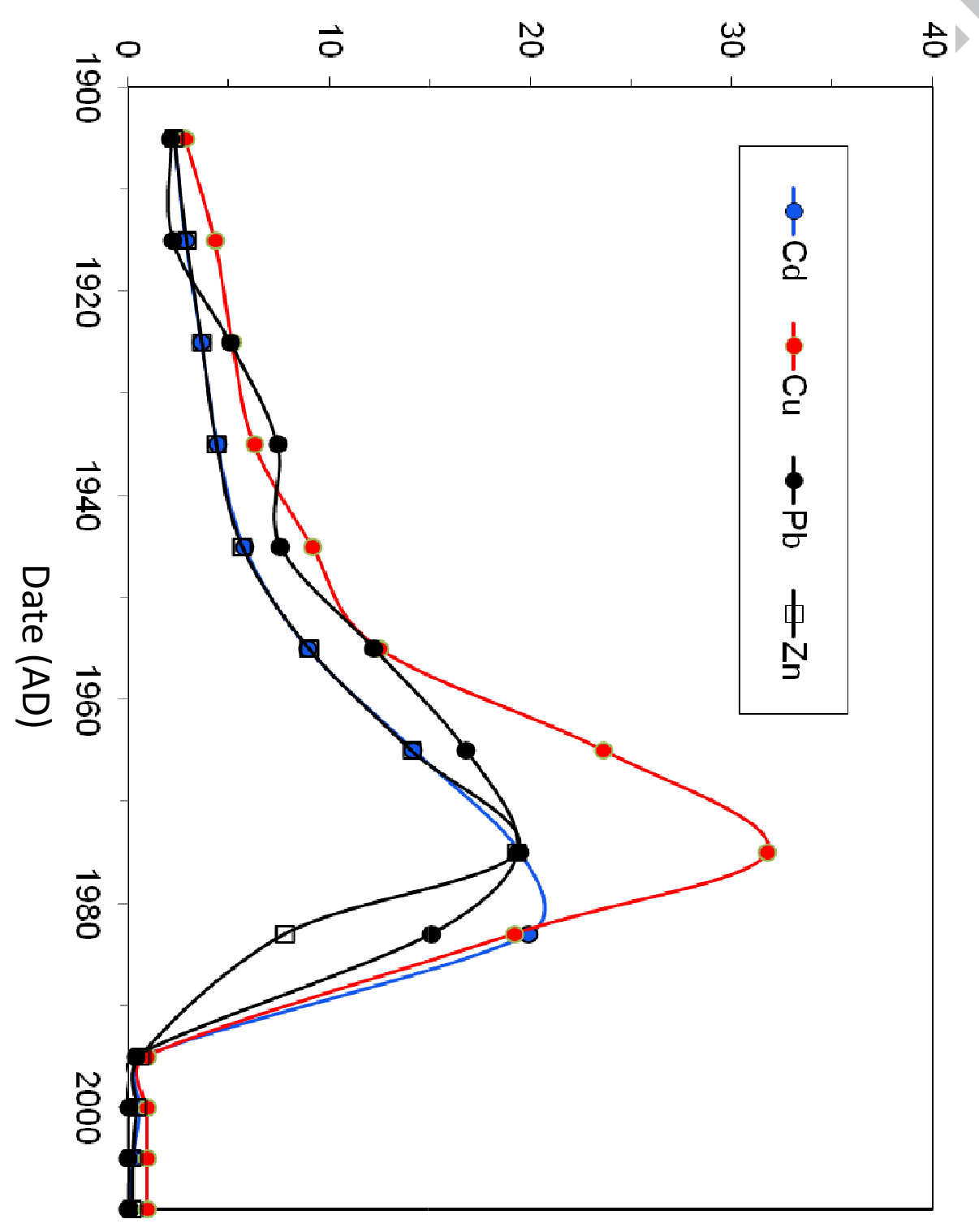




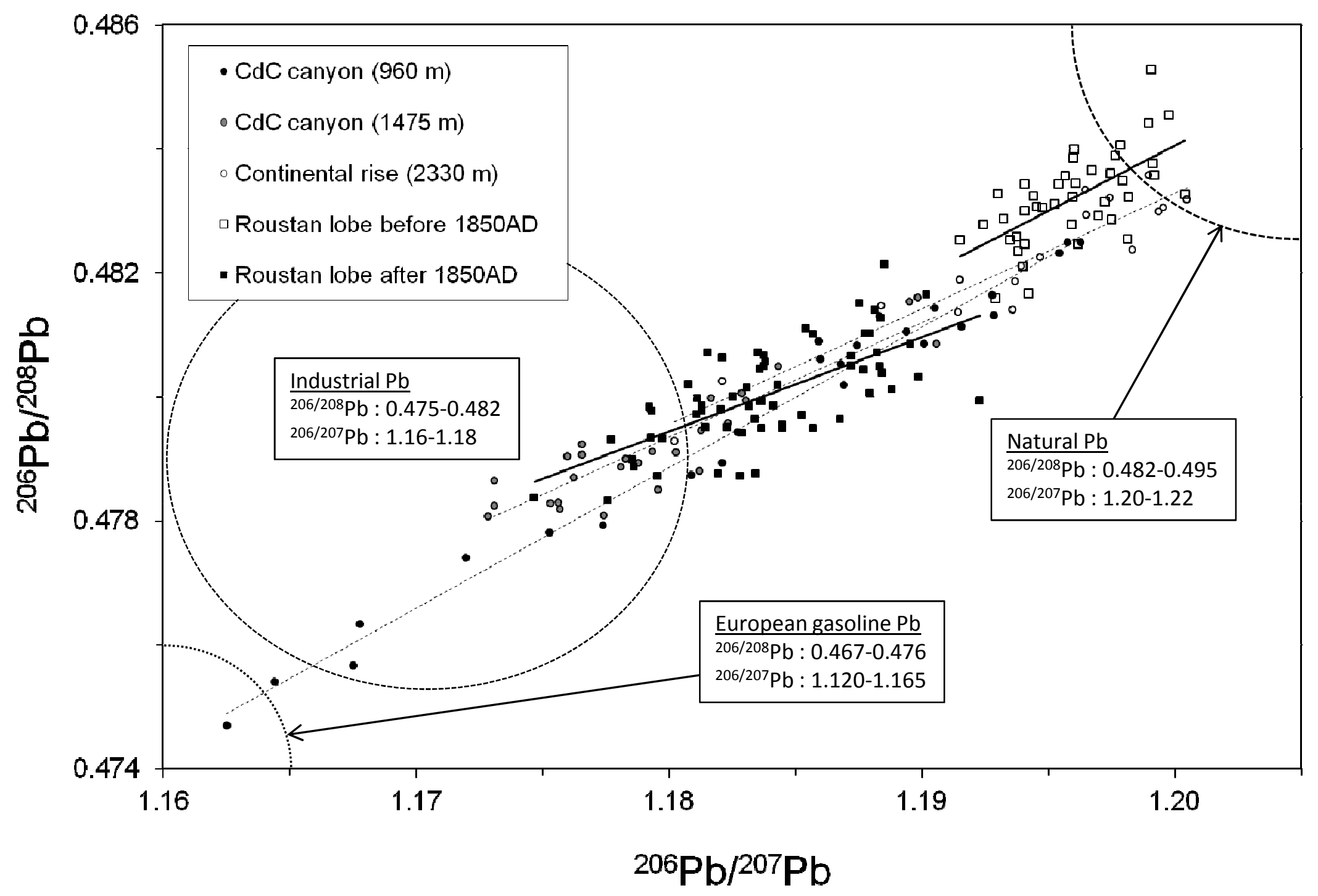

Fig. 8 


\section{Tables}

Table 1. Summary statistics on trace element concentrations and $\mathrm{Pb}$ stable isotopic ratios in the KS57 core. Mean ${ }_{a}$ : arithmetic mean; Mean : Geometric mean (used for log-Normal frequency distributions); SD: Standard deviation; N: number of sediment layers analyzed. EUC refers to average composition of Earth's upper crust (values compiled by Li, 2000).

Table 2. Pearson correlation coefficients between element concentrations for the pre-industrial period. Bolt values refer to the significance of the correlation $(\mathrm{p}<0.01)$.

Table 3. Principal component analyses. Correlation coefficients between variables and the first components (F1 to F3), (a) before and (b) after $1850 \mathrm{AD}$. In brackets, the percentages of the total variability explained by each component. Bolt values refer to the significance of the correlation $(\mathrm{p}<0.01)$.

Table 4. Presence of peaks in the TE/Al ratio distribution profiles. Peak numbers are those given on Figures 5 and 6. Number of " $\mathrm{x}$ " is proportional to the amplitude of the peaks. No water discharge value is available before 1850. (1) Association Nazairienne de Généalogie. Epidémies et famines en France : Climats et épidémies. http://angeneasn.free.fr/epidemies.htm; (2) Fournet (21012) ; (3) Champion (1862) ; (4) Compagnie Générale du Rhône. http://www.ecologie-etprogres.com/crue.htm; (5) Pardé (1928); (6) Pardé (1948). 
Table 1. Summary statistics on trace element concentrations and $\mathrm{Pb}$ stable isotopic ratios in the KS57 core. Mean $_{a}$ : arithmetic mean; Mean ${ }_{g}$ Geometric mean; SD: Standard deviation; N: number of sediment layers analyzed. EUC refers to average composition of Earth's upper crust (values compiled by Li, 2000).

\begin{tabular}{|c|c|c|c|c|c|c|c|c|c|c|c|}
\hline & $\begin{array}{r}\text { Ag } \\
\mu g / g\end{array}$ & $\begin{array}{c}\text { Cd } \\
\mu g / g\end{array}$ & $\begin{array}{c}\text { Co } \\
\mu g / g\end{array}$ & $\begin{array}{c}\mathbf{C r} \\
\mu g / g\end{array}$ & $\begin{array}{c}\mathbf{C u} \\
\mu g / g\end{array}$ & $\begin{array}{c}\mathbf{N i} \\
\mu g / g\end{array}$ & $\begin{array}{c}\mathbf{P b} \\
\mu g / g\end{array}$ & $\begin{array}{c}\mathbf{Z n} \\
\mu g / g\end{array}$ & ${ }^{206 / 207} \mathrm{~Pb}$ & ${ }^{206 / 208} \mathrm{~Pb}$ & $\begin{array}{c}{ }^{206 / 204} \mathrm{~Pb} \\
-\end{array}$ \\
\hline $\operatorname{Mean}_{a}(1850-2008)$ & 0.35 & 0.32 & 12.34 & 73.47 & 31.96 & 41.09 & 41.71 & 107.50 & 1.1839 & 0.4800 & 18.5306 \\
\hline SD (1850-2008) & 0.24 & 0.22 & 1.83 & 11.72 & 7.83 & 3.68 & 19.14 & 25.05 & 0.0036 & 0.0008 & 0.0722 \\
\hline N (1850-2008) & 61 & 61 & 62 & 62 & 62 & 62 & 62 & 62 & 62 & 62 & 62 \\
\hline $\operatorname{Mean}_{a}(1600-1850)$ & 0.10 & 0.17 & 12.09 & 70.23 & 23.54 & 41.82 & 22.31 & 80.57 & 1.1955 & 0.4831 & 18.7276 \\
\hline SD (1600-1850) & 0.02 & 0.02 & 1.09 & 3.83 & 1.68 & 1.84 & 2.91 & 5.25 & 0.0025 & 0.0008 & 0.0430 \\
\hline N (1600-1850) & 43 & 43 & 43 & 43 & 43 & 43 & 43 & 43 & 42 & 42 & 42 \\
\hline $\operatorname{Mean}_{g}(1600-2008)$ & 0.18 & 0.22 & 12.14 & 71.56 & 27.73 & 41.27 & 30.85 & 94.07 & 1.1886 & 0.4813 & 18.6098 \\
\hline $\begin{array}{l}\text { Median (1600-2008) } \\
\text { N (1600-2008) }\end{array}$ & $\begin{array}{l}0.14 \\
104\end{array}$ & $\begin{array}{l}0.20 \\
104\end{array}$ & $\begin{array}{c}12.00 \\
105\end{array}$ & 70.70 & $\begin{array}{l}26.40 \\
105\end{array}$ & $\begin{array}{c}41.35 \\
105\end{array}$ & $\begin{array}{c}28.85 \\
105\end{array}$ & $\begin{array}{c}88.20 \\
105\end{array}$ & $\begin{array}{c}1.1880 \\
104\end{array}$ & $\begin{array}{c}0.4807 \\
104\end{array}$ & $\begin{array}{c}18.5995 \\
104\end{array}$ \\
\hline EUC & 0.05 & 0.10 & $10-18$ & 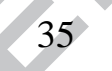 & 25 & $20-56$ & $17-20$ & 71 & - & - & - \\
\hline
\end{tabular}


Table 2. Pearson correlation coefficients between element concentrations for the preindustrial period. Bolt values refer to the significance of the correlation $(p<0.01)$.

\begin{tabular}{|c|c|c|c|c|c|c|c|c|c|c|c|c|c|}
\hline & $\mathrm{C}_{\text {org }}$ & Carbonates & $\mathrm{Ag}$ & $\mathrm{Cd}$ & $\mathrm{Co}$ & $\mathrm{Cr}$ & $\mathrm{Cu}$ & $\mathrm{Li}$ & $\mathrm{Mn}$ & $\mathrm{Ni}$ & $\mathrm{Pb}$ & $\mathrm{Zn}$ & $\mathrm{Al}$ \\
\hline $\mathrm{C}_{\text {org }}$ & 1 & & & & & & & & & & & & \\
\hline Carbonates & -0.41 & 1 & & & & & & & & & & & \\
\hline $\mathrm{Ag}$ & -0.29 & 0.18 & 1 & & & & & & & & & & \\
\hline $\mathrm{Cd}$ & -0.27 & 0.36 & 0.63 & 1 & & & & & & & & & \\
\hline Co & -0.18 & 0.40 & 0.17 & 0.31 & 1 & & & & & & & & \\
\hline $\mathrm{Cr}$ & 0.01 & 0.17 & -0.09 & -0.03 & 0.52 & 1 & & & & & & & \\
\hline $\mathrm{Cu}$ & -0.22 & 0.29 & 0.36 & 0.45 & 0.69 & 0.56 & 1 & & & & & & \\
\hline $\mathrm{Li}$ & 0.11 & 0.07 & -0.04 & 0.03 & 0.42 & 0.93 & 0.53 & & & & & & \\
\hline Mn & -0.26 & 0.54 & 0.34 & 0.31 & 0.55 & 0.22 & 0.57 & 0.14 & 1 & & & & \\
\hline $\mathrm{Ni}$ & -0.03 & 0.08 & 0.01 & 0.03 & 0.71 & 0.81 & 0.66 & 0.69 & 0.31 & 1 & & & \\
\hline $\mathrm{Pb}$ & -0.29 & 0.47 & 0.40 & 0.48 & 0.42 & 0.50 & 0.64 & 0.48 & 0.60 & 0.33 & 1 & & \\
\hline $\mathrm{Zn}$ & -0.15 & 0.22 & 0.36 & 0.51 & 0.57 & 0.56 & 0.84 & 0.61 & 0.39 & 0.60 & 0.72 & 1 & \\
\hline $\mathrm{Al}$ & -0.25 & 0.32 & 0.26 & 0.17 & 0.38 & 0.68 & 0.50 & 0.71 & 0.36 & 0.47 & 0.64 & 0.55 & 1 \\
\hline $\mathrm{Fe}$ & 0.02 & -0.33 & -0.03 & -0.26 & -0.17 & 0.40 & -0.06 & 0.37 & -0.13 & 0.17 & 0.09 & -0.12 & 0.25 \\
\hline
\end{tabular}


Table 3. Principal Component Analyses. Correlation between variables and the first four components (F1 to F3). In brackets the percentages of the total variability explained by each component. Bolt values refer to the significance of the correlation $(\mathrm{p}<0.01)$.

\begin{tabular}{|c|c|c|c|}
\hline Before 1850 & F1 $(42 \%)$ & F2 (19\%) & F3 (9\%) \\
\hline $\mathrm{C}_{\text {org }}$ & -0.283 & -0.451 & -0.282 \\
\hline Carbonates & 0.458 & 0.498 & -0.169 \\
\hline $\mathrm{Ag}$ & 0.372 & 0.558 & 0.461 \\
\hline $\mathrm{Cd}$ & 0.456 & 0.631 & 0.165 \\
\hline Co & 0.751 & 0.056 & -0.464 \\
\hline $\mathrm{Cr}$ & 0.757 & -0.601 & -0.005 \\
\hline $\mathrm{Cu}$ & 0.874 & 0.081 & -0.137 \\
\hline $\mathrm{Li}$ & 0.720 & -0.603 & 0.079 \\
\hline $\mathrm{Mn}$ & 0.623 & 0.380 & -0.139 \\
\hline $\mathrm{Ni}$ & 0.734 & -0.433 & -0.296 \\
\hline $\mathrm{Pb}$ & 0.807 & 0.188 & 0.273 \\
\hline $\mathrm{Zn}$ & 0.853 & 0.045 & -0.041 \\
\hline $\mathrm{Al}$ & 0.754 & -0.192 & 0.321 \\
\hline $\mathrm{Fe}$ & 0.064 & -0.598 & 0.645 \\
\hline After 1850 & F1 $(49 \%)$ & $\mathrm{F} 2(28 \%)$ & F3 (9\%) \\
\hline $\mathrm{C}_{\mathrm{org}}$ & -0.405 & 0.001 & 0.805 \\
\hline Carbonates & 0.356 & -0.667 & -0.521 \\
\hline $\mathrm{Ag}$ & 0.771 & -0.556 & 0.164 \\
\hline $\mathrm{Cd}$ & 0.827 & -0.335 & 0.272 \\
\hline Co & 0.520 & 0.742 & 0.153 \\
\hline $\mathrm{Cr}$ & 0.964 & 0.068 & 0.007 \\
\hline $\mathrm{Cu}$ & 0.930 & -0.271 & 0.137 \\
\hline $\mathrm{Li}$ & 0.370 & 0.865 & -0.200 \\
\hline $\mathrm{Mn}$ & 0.071 & 0.905 & 0.119 \\
\hline $\mathrm{Ni}$ & 0.691 & 0.657 & -0.011 \\
\hline $\mathrm{Pb}$ & 0.829 & -0.209 & 0.163 \\
\hline $\mathrm{Zn}$ & 0.944 & -0.211 & 0.110 \\
\hline $\mathrm{Al}$ & 0.544 & 0.519 & -0.217 \\
\hline $\mathrm{Fe}$ & 0.865 & -0.005 & -0.117 \\
\hline
\end{tabular}


Table 4. Presence of peaks in the TE/Al ratio distribution profiles. Peak numbers are those given on Figures 5 and 6. Number of " $x$ " is proportional to the amplitude of the peaks. No water discharge value is available before 1850. (1) Association Nazairienne de Généalogie. Epidémies et famines en France : Climats et épidémies. http://angeneasn.free.fr/epidemies.htm; (2) Fournet (21012) ; (3) Champion (1862) ; (4) Compagnie Générale du Rhône. http://www.ecologie-etprogres.com/crue.htm; (5) Pardé (1928) ; (6) Pardé 1948).

\begin{tabular}{|c|c|c|c|c|c|c|c|c|c|c|c|c|c|c|}
\hline Peak & $\mathrm{Ag} / \mathrm{Al}$ & $\mathrm{Cd} / \mathrm{Al}$ & $\mathrm{Pb} / \mathrm{Al}$ & $\mathrm{Zn} / \mathrm{Al}$ & $\mathrm{Cu} / \mathrm{Al}$ & $\mathrm{Co} / \mathrm{Al}$ & $\mathrm{Cr} / \mathrm{Al}$ & $\mathrm{Ni} / \mathrm{Al}$ & Documented flooding & RR discharge $\left(\mathrm{m}^{3} \mathrm{~s}^{-1}\right)$ & Interval & Date (AD) & Remarks & Ref. \\
\hline 1 & $\mathrm{xx}$ & $\mathrm{x}$ & $\mathrm{x}$ & $\mathrm{x}$ & $\mathrm{x}$ & $\mathrm{x}$ & $\mathrm{x}$ & $\mathrm{x}$ & $?$ & & I & $\sim 1620$ & Cold and long winter 1620-21 & 1,2 \\
\hline 2 & $\mathrm{xx}$ & $\mathrm{xx}$ & & $\mathrm{xx}$ & $\mathrm{xx}$ & $\mathrm{xx}$ & $\mathrm{x}$ & $\mathrm{xx}$ & Nov. 1694 & & I-II & -1695 & Mn-enrichment & 3 \\
\hline 3 & $\mathrm{xx}$ & & $\mathrm{xx}$ & $\mathrm{x}$ & $\mathrm{x}$ & & & & $1774-77$ & & II & $\sim 1775$ & & 3 \\
\hline 4 & $\mathrm{xx}$ & $\mathrm{xx}$ & $\mathrm{xx}$ & $\mathrm{xx}$ & & & & & $?$ & 1856: 11640 & IIIIII & $\sim 1850$ & Milenium record & 3 \\
\hline 5 & $\mathrm{xx}$ & & $\mathrm{xxx}$ & $\mathrm{xx}$ & & & & & Janv. 1889, Sept. 1890, Oct. 1891 & 1889: 8780; 1891: 7800 & III & $\sim 1890$ & & 4 \\
\hline 6 & & $\mathrm{x}$ & & & & $\mathrm{x}$ & & $\mathrm{x}$ & Nov. 1896 & 9060 & III-IV & $\sim 1896$ & Mn-enrichment & 4 \\
\hline 7 & $\mathrm{xxx}$ & $\mathrm{xxx}$ & $\mathrm{xxx}$ & $\mathrm{xxx}$ & $\mathrm{xxx}$ & $\mathrm{x}$ & $\mathrm{x}$ & $\mathrm{x}$ & Dec. 1926 & 7400 & IV & $\sim 1926$ & & 5 \\
\hline 8 & $\mathrm{xx}$ & $\mathrm{xx}$ & $\mathrm{xx}$ & $\mathrm{xx}$ & & & & & Nov. 1944, Fev. 1945 & $>7500$ & IV & $\sim 1944$ & & 6 \\
\hline 9 & & $\mathrm{xx}$ & $\mathrm{x}$ & $\mathrm{x}$ & $\mathrm{x}$ & & & & Nov. 1963 & $>3660$ & IV & $\sim 1964$ & & 4 \\
\hline 10 & xxxx & xxxx & $\mathrm{xxxx}$ & $\mathrm{xxxx}$ & $\mathrm{xxxx}$ & & & & Nov. 1977 & 8690 & IV & $\sim 1976$ & & 4 \\
\hline 11 & $\mathrm{xxx}$ & $\mathrm{xxx}$ & $\mathrm{xx}$ & $\mathrm{xx}$ & $\mathrm{xx}$ & $\mathrm{x}$ & $\mathrm{x}$ & $\mathrm{x}$ & Oct. 1993, Janv. 1994, Nov. 1996 & $9800,11000,8980$ & IV & $\sim 1995$ & Mn-enrichment & 4 \\
\hline 12 & $\mathrm{xx}$ & & $\mathrm{xx}$ & & & & & & Sept., Nov. 2002 & 10500,10200 & IV & $\sim 2000$ & & 4 \\
\hline 13 & & $\mathrm{xx}$ & $\mathrm{xx}$ & & & & & & Dec. 2003 & 11500 & IV & $\sim 2004$ & & 4 \\
\hline
\end{tabular}

